\title{
Contrasting cyanobacterial communities and microcystin concentrations in summers with extreme weather events: insights into potential effects of climate change
}

\author{
Susanna A. Wood $(\mathbb{D} \cdot$ Hugo Borges $\cdot$ Jonathan Puddick $\cdot$ Laura Biessy \\ Javier Atalah • Ian Hawes • Daniel R. Dietrich • David P. Hamilton
}

\begin{abstract}
Current climate change scenarios predict that aquatic systems will experience increases in temperature, thermal stratification, water column stability and in some regions, greater precipitation. These factors have been associated with promoting cyanobacterial blooms. However, limited data exist on how cyanobacterial composition and toxin production will be affected. Using a shallow eutrophic lake, we investigated how precipitation intensity and extended droughts influenced: (i) physical and chemical conditions, (ii) cyanobacterial community succession, and (iii) toxin production by Microcystis. Moderate levels of nitrate related to intermittent high rainfall during the summer of 2013-2014, lead to the dominance of
\end{abstract}

Handling editor: Judit Padisák

S. A. Wood $(\bowtie) \cdot$ H. Borges $\cdot$ J. Puddick ·

L. Biessy - J. Atalah

Cawthron Institute, Private Bag 2, Nelson, New Zealand e-mail: susie.wood@cawthron.org.nz

\section{S. A. Wood - H. Borges - D. P. Hamilton}

Environmental Research Institute, University of Waikato, Hamilton, New Zealand

\section{Hawes}

Waterways Centre for Freshwater Management, University of Canterbury, Christchurch, New Zealand

\section{R. Dietrich}

Faculty of Biology, University of Konstanz, Constance, Germany
Aphanizomenon gracile and Dolichospermum crassum (without heterocytes). Microcystis aeruginosa blooms occurred when ammonium concentrations and water temperature increased, and total nitrogen:total phosphorus ratios were low. In contrast, an extended drought (2014-2015 summer) resulted in prolonged stratification, increased dissolved reactive phosphorus, and low dissolved inorganic nitrogen concentrations. All A. gracile and D. crassum filaments contained heterocytes, $M$. aeruginosa density remained low, and the picocyanobacteria Aphanocapsa was abundant. A positive relationship $(P<0.001)$ was identified between microcystin quotas and surface water temperature. These results highlight the complex successional interplay of cyanobacteria species and demonstrated the importance of climate through its effect on nutrient concentrations, water temperature, and stratification.

Keywords Aphanizomenon - Dolichospermum . Microcystis - Surface water temperature · Nitrogen · Phosphorus

\section{Introduction}

The occurrence of cyanobacterial blooms is increasing in lakes across the globe (Garcia-Pichel et al., 2003; Paerl \& Otten, 2013; Harke et al., 2016). Cyanobacterial blooms can have negative environmental 
impacts including reductions in water clarity and dissolved oxygen, which may suppress macrophyte growth and affect invertebrates and fish (Smith, 2003; Paerl, 2014). Many bloom-forming species also produce natural toxins (cyanotoxins) which pose chronic and acute health risks to humans and animals (Chorus, 2001; Codd et al., 2005). Blooms and their associated toxins also have economic and social consequences such as loss of tourism opportunities and increased costs associated with technical upgrades to water treatment plants and additional surveillance responsibilities (Kouzminov et al., 2007; Steffensen, 2008; Hamilton et al., 2014).

Increases in anthropogenic eutrophication have historically been considered to be the main drivers of cyanobacterial proliferations, with the relative importance of both nitrogen $(\mathrm{N})$ and phosphorus $(\mathrm{P})$ inputs debated for many decades (e.g. Smith, 1983; Lewis \& Wurtsbaugh, 2008; Schindler et al., 2008; Conley et al., 2009; Ahn et al., 2011; Smith et al., 2016). In recent years, the impacts of global climate change on the distribution and intensity of cyanobacterial blooms has attracted considerable scientific and media attention (Paerl \& Huisman, 2008, 2009; Brookes \& Carey, 2011; Carey et al., 2012; Kosten et al., 2012; Paerl \& Paul, 2012). Most climate change models predict that aquatic systems will experience increases in temperature, thermal stratification, and water column stability, all factors associated with promoting cyanobacterial blooms (Jöhnk et al., 2008; Wagner \& Adrian, 2009; Trolle et al., 2010; Kosten et al., 2012). Less attention has been given to how other variables linked to climate change, such as variations in precipitation, extended droughts, or increased carbon dioxide levels, might affect cyanobacterial biomass (O'Neil et al., 2012; Reichwaldt \& Ghadouani, 2012). For example, prolonged and intense precipitation events can mobilise nutrients and sediments on land and increase nutrient enrichment of receiving waterbodies (Paerl et al., 2006).

Understanding the effects of climate change on cyanobacterial blooms is complicated by successional patterns in cyanobacterial communities. For example, Fernández et al. (2015) tracked the succession of Microcystis spp. and Dolichospermum (basionym Anabaena) circinale (Rabenhorst ex Bornet \& Flahault) P. Wacklin, L. Hoffmann \& J. Komárek during a bloom, and identified $\mathrm{P}$, temperature and solar radiation as key factors in regulating shifts in their relative composition. Despite this and other examples (e.g. Rajaniemi-
Wacklin et al., 2008; Ni et al., 2012; Cai \& Kong, 2013), most research to date has focused on monospecific blooms with the consequence that knowledge on cyanobacterial succession is limited (Fernández et al., 2015). A further layer of complexity is that among cyanobacterial species known to produce cyanotoxins, both toxic and non-toxic genotypes can exist. Blooms are usually comprised both, and these can currently only be distinguished in the natural environment via molecular techniques (Kurmayer \& Kutzenberger, 2003). Factors that promote one genotype to dominate over another are also largely unknown (Rinta-Kanto et al., 2009; Van de Waal et al., 2011), and predicting how these might shift with climate change is challenging (Wood et al., 2015). Furthermore, the amount of toxin produced by toxic strains is variable, and factors such as temperature (Dziallas \& Grossart, 2011; Kleinteich et al., 2012) and nutrients (Harke \& Gobler, 2013; Horst et al., 2014) may be involved in regulating production and therefore also influenced by climate change.

To date, most research investigating how variables linked with climate change might affect cyanobacterial biomass, species succession, genotype abundance, and toxin production has been based on models or culture-based studies, and there is uncertainty around the applicability of these data to real-world situations (Wood et al., 2015). Natural population surveys undertaken over consecutive years with contrasting and extreme climatic conditions may provide valuable insights and begin to address this uncertainty. Lake Rotorua (South Island, New Zealand; Fig. 1) is a shallow eutrophic lake which experiences annual cyanobacterial blooms between spring and autumn (Wood et al., 2011, 2012a). During the summer of 2013-2014, the North Canterbury region of New Zealand (where Lake Rotorua is situated) experienced a series of rainfall events including intense precipitation from tropical cyclones Lusi (March 2014) and Ita (April 2014) as they transitioned into sub-tropical weather systems over New Zealand. In contrast, this region experienced a severe drought in the summer of 2014-2015, with the second lowest total rainfall (over the summer period) measured since records began 75 years before present. These contrasting weather patterns provided a unique opportunity to explore how differences in climate affect physical and chemical parameters in a shallow eutrophic lake, and the subsequent influence on cyanobacterial biomass, community composition, and toxin concentrations. 
Fig. 1 Map of Lake Rotorua (South Island, New Zealand) showing the sampling site and thermistor chain sites 1 (January-April 2014) and 2 (May 2014May 2015). Inset map of New Zealand showing the location of the lake

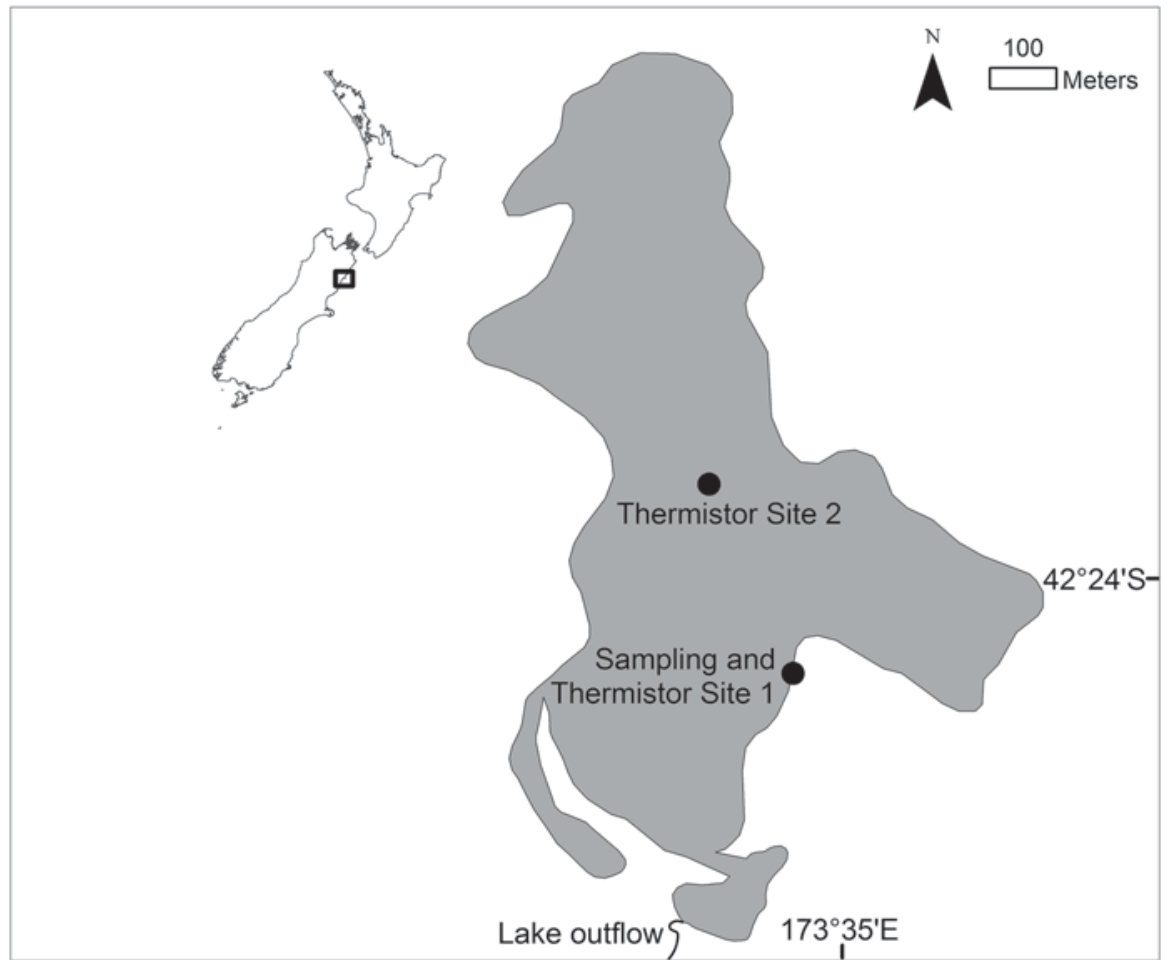

The aim of this study was to use a dataset collected from Lake Rotorua at weekly or fortnightly intervals between January 2014 and May 2015 to address the following three questions: (i) How are physical and chemical conditions within a shallow eutrophic lake affected by contrasting temperature and precipitation regimes over consecutive summers? (ii) Do physical and chemical changes affect cyanobacterial biomass, composition, and succession, and which parameter(s) are the key drivers of any observed changes? (iii) Did the relative abundance of toxic and non-toxic Microcystis genotypes, and toxin quota vary between the two summers and what were the possible drivers of these differences? Our final question focused specifically on Microcystis, as this is the only known toxin-producing cyanobacteria genus in Lake Rotorua (Wood et al., 2011, 2012a).

\section{Materials and methods}

Study site and sample collection

Lake Rotorua (South Island, New Zealand $42^{\circ} 24^{\prime} 05 \mathrm{~S}$, $173^{\circ} 34^{\prime} 57 \mathrm{E}$ ) is a small $\left(0.55 \mathrm{~km}^{2}\right)$, shallow (max. depth $3 \mathrm{~m}$ ), eutrophic lake in the northeast of the South Island of New Zealand (Flint, 1975). The native podocarp-mixed hardwood forest that once dominated the catchment was removed in the early 1900s. The catchment now comprises mixed land use of lowintensity grazing, regenerating native scrub and bushland, and exotic weeds and trees. Inflow is largely from surface run-off during rainfall events. During high rainfall, there is discharge from a small outflow at the southern end of the lake (Fig. 1). The changes in catchment land-use, resulting in greater nitrate and sediment run-off, coupled with a long residence time are likely reasons for the eutrophication of this lake. With its close proximity to the sea, Lake Rotorua experiences a relatively mild climate. The average temperature in the nearby town of Kaikoura is $12.7^{\circ} \mathrm{C}$ and precipitation averages $881 \mathrm{~mm}$. The climate in this region is classified as Cfb by the Köppen-Geiger system.

Temperature was measured at 5- or 15-min intervals using temperature loggers $\left(\mathrm{HOBO}^{\circledR}\right.$, Onset). Initially, this was undertaken from the end of a floating pontoon (January-April 2014; Fig. 1) with a chain of loggers at the lake surface $(0 \mathrm{~m})$, and 0.3 , 
$0.45,0.9$, and $1.5 \mathrm{~m}$ below the water surface. Thereafter, the chain was positioned at a central point in the lake (Fig. 1) with loggers at the lake surface, and 0.8, $1.0,1.4,1.7,2.0$, and $2.6 \mathrm{~m}$ below the surface. To enable the data loggers to be maintained at a constant distance from the surface regardless of fluctuations in lake level, the thermistor chain was attached to a buoy floating on the surface of the lake. Daily mean rainfall and maximum air temperature data at the Kaikoura weather station (situated approximately $8 \mathrm{~km}$ from the study site) were obtained from the Cliflow database of the National Institute of Water and Atmospheric Research, New Zealand.

Between January 2014 and May 2015, surface water samples $(400 \mathrm{ml})$ were collected weekly or fortnightly from the end of a floating pontoon $(15 \mathrm{~m}$ in length) on the eastern side of the lake (Fig. 1). Samples were stored chilled and in the dark, and were received at the laboratory within $24 \mathrm{~h}$. Samples were subsequently well mixed and six sub-samples were taken: (1) $45 \mathrm{ml}$ of pre-filtered lake water $(20-\mu \mathrm{m}$ netting) was syringe-filtered (Whatman GF/C), and the filtrate was frozen $\left(-20^{\circ} \mathrm{C}\right)$ for dissolved nutrients analysis; (2) $45 \mathrm{ml}$ of lake water was frozen $\left(-20^{\circ} \mathrm{C}\right)$ for total nutrient analysis; (3) $15 \mathrm{ml}$ of lake water was preserved using Lugol's iodine for microscopic analysis; (4) 15-60 ml was filtered onto Whatman GF/C filters which were stored frozen $\left(-20^{\circ} \mathrm{C}\right)$ for DNA extraction; (5) $5 \mathrm{ml}$ of pre-filtered lake water $(20-\mu \mathrm{m}$ netting) was syringe-filtered (Whatman GF/C), and the filtrate was frozen $\left(-20^{\circ} \mathrm{C}\right)$ for extracellular microcystin analysis; and (6) $5 \mathrm{ml}$ of lake water was frozen $\left(-20^{\circ} \mathrm{C}\right)$ for total microcystin analysis.

\section{Laboratory analysis of weekly/fortnightly samples}

Total and filtered nutrients were analysed on a Lachat QuickChem $^{\circledR}$ flow injection analyser (FIA+ 8000 Series, Zellweger Analytics, Inc.) using the methods provided in APHA (2005). The nutrient species were analysed as ammonium $\left(\mathrm{NH}_{4}-\mathrm{N}\right)$, nitrite $\left(\mathrm{NO}_{2}-\mathrm{N}\right)$, nitrate $\left(\mathrm{NO}_{3}-\mathrm{N}\right)$, total $\mathrm{N}(\mathrm{TN})$, dissolved reactive $\mathrm{P}$ (DRP), and total $\mathrm{P}$ (TP). The limits of quantification were $0.002 \mathrm{mg} \mathrm{l}^{-1}$ for $\mathrm{NH}_{4}-\mathrm{N}, 0.001 \mathrm{mg} \mathrm{l}^{-1} \mathrm{NO}_{2}-\mathrm{N}$, and $\mathrm{NO}_{3}-\mathrm{N}$, and $0.004 \mathrm{mg} \mathrm{l}^{-1}$ for TN, DRP, and TP.

Cyanobacterial identification and enumeration was undertaken using an inverted microscope (IX70, Olympus). To assist in accurate enumeration, samples were mechanically ground (Tissue Grinder, Wheaton,
USA) for ca. 30 s to break up Microcystis colonies and filamentous species. Sub-samples $(0.5-1 \mathrm{ml})$ were settled in Utermöhl chambers (1958), and cyanobacteria cells and heterocytes were enumerated by scanning one-two transects at $\times 400-600$ magnification. Species identification was undertaken with reference to Baker and Fabbro (2002), McGregor \& Fabbro (2001), Wood et al. (2005), and Komárek \& Anagnostidis (1999). A second sub-sample (unground) from approximately every second sample was prepared as described above, and all noncyanobacterial phytoplankton were identified and enumerated. Biovolumes were determined for each species using median cell dimensions $(n=30-50)$ measured at $\times 1,000$ magnification under oil immersion (Olympus BX51) and volumetric equations of geometric shapes closest to each cell shape (Sun \& Liu, 2003).

Microcystis sp. strain CAWBG617, isolated from Lake Rotorua (Rogers, 2014), was grown in a glass flask $(500 \mathrm{ml})$ in MLA medium (Bolch \& Blackburn, 1996) under a light regime of $90 \mu \mathrm{mol} \mathrm{s}{ }^{-1} \mathrm{~m}^{-2}$ with a 12:12-h light/dark cycle, at a temperature of $18 \pm 1^{\circ} \mathrm{C}$. When the culture was in the exponential growth phase, a sub-sample $(60 \mathrm{ml})$ was filtered (Whatman GF/C) and the filter stored frozen $\left(-20^{\circ} \mathrm{C}\right)$ for DNA extraction. This was used to prepare a standard curve for the quantitative polymerase chain reaction (QPCR) assay used to assess toxic genotype concentrations. A second sub-sample $(10 \mathrm{ml})$ was preserved using Lugol's iodine and the cell concentration determined by microscopy (as described above).

DNA was extracted from GF/C filters using a power soil DNA isolation kit (Mo Bio, USA) according to the protocol supplied by the manufacturer. All DNA samples from the Lake Rotorua samples were screened in duplicate for inhibition using an internal control assay. Each $12.5 \mu \mathrm{l}$ reaction contained $6.25 \mu \mathrm{l}$ Kapa probe fast QPCR kit master mix $(\times 2), 1 \mu \mathrm{l}$ of primers targeting the internal transcribed spacer region 2 of the rRNA gene operon of Oncorhynchus keta salmon sperm $(0.4 \mu \mathrm{M}$, Sketa F2 and Sketa R3, Integrated DNA Technologies, USA Haugland et al., 2005), $1 \mu$ l TaqMan probe synthesised with a FAM reporter dye at the $5^{\prime}$-end and a Black Hole Quencher 2 at the $3^{\prime}$-end $(0.2 \mu \mathrm{M}$, Sketa P2, Integrated DNA Technologies, USA; Haugland et al., 2005), $1 \mu \mathrm{l}$ extracted salmon sperm DNA (15 ng, Sigma, USA), 
and $1 \mu \mathrm{l}$ of template DNA. The cycling profile was $95^{\circ} \mathrm{C}$ for $3 \mathrm{~min}$, followed by 50 cycles at $95^{\circ} \mathrm{C}$ for $3 \mathrm{~s}$ and $58^{\circ} \mathrm{C}$ for $10 \mathrm{~s}$. When inhibition was observed samples were diluted (1/10) and re-analysed.

QPCR, used to enumerate to the copy numbers of $m c y E$ genes, was undertaken in triplicate for each sample in a $12.5 \mu \mathrm{l}$ of reaction mix containing $6.25 \mu \mathrm{l}$ Kapa probe fast QPCR kit master mix $(\times 2), 1 \mu 1$ of primers targeting a region within the mcyE open reading frame of the microcystin synthase gene $(0.4 \mu \mathrm{M}$, mcyE-F2 and MicmcyE-R8; Vaitomaa et al., 2003), $0.2 \mu \mathrm{l}$ of McyE probe (Rueckert \& Cary, 2009), and $1 \mu \mathrm{l}$ of template DNA per sample. DNA from CAWBG617 was used to generate five-point standard curves ranging from $10.8 \times 10^{2}$ to $10.8 \times 10^{6}$ cells ml $^{-1}$. Each point of the standard curve was analysed in triplicate for each QPCR run conducted. The standard curve generated was linear $\left(R^{2}>0.99\right)$ and PCR efficiency was $>0.8$.

Sub-samples collected for extracellular microcystin were centrifuged $(10,000 \times g, 5 \mathrm{~min})$, and the supernatant was placed in a septum-capped vial. Subsamples for total microcystin analysis were freezethawed and sonicated $(30 \mathrm{~min}, 60 \mathrm{kHz})$ four times after adding formic acid (final concentration $0.1 \%$ $\mathrm{v} / \mathrm{v})$. The extract was clarified by centrifugation $(10,000 \times g, 5 \mathrm{~min})$ and the supernatant was placed in a septum-capped vial. Microcystin samples were analysed directly or diluted (1/10-1/100 with 50\% methanol containing $0.1 \%$ formic acid) by liquid chromatography-tandem mass spectrometry as described in Wood et al. (2012b) and Clearwater et al. (2014). Primary standards of the microcystin congeners -RR, -YR, and -LR were purchased from DHI Lab Products (Denmark). The amount of microcystin per toxic cell was calculated by summing the concentration of all congeners in the samples, subtracting the extracellular microcystin values from the total microcystin values, and dividing this value by the $m c y \mathrm{E}$ copies $\mathrm{ml}^{-1}$ (as determined using QPCR).

Data and statistical analysis

Thermocline depth was quantified using the rLakeAnalyzer package with the software $\mathrm{R}$ with a daily smoothing function applied (R Development Core Team, 2014). Differences in environmental variables between the summers of 2014 (for this study defined as January-May 2014) and 2015 (January-May 2015) were evaluated. These were tested using a one-way ANOVA analyses with year as a fixed factor. Response variables were transformed if necessary, to fulfil the assumptions of normality and heterogeneity of variance.

The relationship between cyanobacterial community composition (measured as biovolumes) and environmental variables was analysed using multivariate multiple regression (McArdle \& Anderson, 2001), using the DistLM routine in the PRIMER 6 and PERMANOVA (Anderson et al., 2008). A marginal test was used where individual variables were fitted separately to test their relationship with the cyanobacterial data (ignoring other variables), followed by a step-wise selection procedure, conditional on variables already included in the model and using the Akaike information criterion (AIC) with a correction for finite sample sizes $\left(\mathrm{AIC}_{\mathrm{c}}\right)$ selection criteria. The conditional test identifies the subset of variables that best predicts the observed pattern in cyanobacterial community composition. Both the conditional and marginal tests were undertaken with 4,999 permutations using Bray-Curtis similarities of the $\log +1$ transformed cyanobacterial biovolume data. Draftsman plots were used to check multi-skewness among environmental variables, and all were $\log +1$ transformed prior to the analysis and included: $\mathrm{NO}_{2}-\mathrm{N}$, $\mathrm{NO}_{3}-\mathrm{N}, \mathrm{NH}_{4}-\mathrm{N}, \mathrm{DRP}$, DIN:DRP, TN, TP, TN:TP, weekly averaged surface water temperature and total weekly rainfall.

The relationship between Microcystis biovolume, percentage of toxic Microcystis cells, microcystin quota, and selected environmental variables was modelled using generalised linear models within the software R (Zuur et al., 2013; R Development Core Team, 2014). Microcystis biovolume and microcystin quotas were modelled using gamma errors and a log link, whereas the percentage of toxic Microcystis cells was modelled using beta error and a logit link (Pinheiro \& Bates, 2000; Zuur et al., 2013).

Initial data exploration was conducted to identify outliers, homogeneity of variances, normality, excess of zeros, collinearity, and the relationship between predictors and response variables following the protocol described in Zuur et al. (2010). Covariates were transformed if necessary to avoid right-skewness and achieve unimodal distributions. Collinearity among predictor variables was initially checked by calculating the variance inflation factor (VIF) for each 
covariate and sequentially dropping the covariate with the highest VIF until all were $<5$ (Zuur et al., 2010). To avoid over-parametrization of the models only TN:TP, $\log$ (DIN:DRP) and surface water temperature were included. Additionally for the analysis of the percentage of toxic Microcystis cells and microcystin quota, Microcystis biovolume was included as a covariate in the initial models. Models were selected using a step-wise process based on generalised AIC and validated by inspecting the normalised quantile residuals.

\section{Results}

Surface water temperature in Lake Rotorua ranged from $5.7^{\circ} \mathrm{C}$ (24 July 2014) to $33^{\circ} \mathrm{C}$ (4 February 2014), and from $5.7^{\circ} \mathrm{C}$ (24 July 2014 ) to $25.9^{\circ} \mathrm{C}$ (22 February 2014) at $2.6 \mathrm{~m}$ depth (Fig. 2). When the thermistor chain was positioned close to the shore (January-April 2014) diurnal stratification was apparent, with the presence of a shallow surface thermocline $(0.1-0.5 \mathrm{~m}$; Fig. 2). From May 2014 to June 2015, when the thermistor chain was positioned mid-lake, a relatively persistent thermocline was present at ca. 1-1.2 $\mathrm{m}$ from October to December 2014, and April-May 2015 (Fig. 2), and at ca. 1.8-2 $\mathrm{m}$ in summer (January-May).

From January and May 2014, total rainfall was $540 \mathrm{~mm}$ compared to $82 \mathrm{~mm}$ during the same period in 2015. During this period, in 2014, there were five large rainfall events $\left(>20 \mathrm{~mm} \mathrm{day}^{-1}\right)$. The two largest were associated with tropical cyclones Lusi (15 March, $79 \mathrm{~mm}$ ) and Ita (17 April, $138 \mathrm{~mm}$; Fig. 3).

From January 2014 to May 2015, $\mathrm{NH}_{4}-\mathrm{N}$ concentrations in the surface water were mostly low $\left(<0.09 \mathrm{mg} \mathrm{l}^{-1}\right.$; Fig. 4A). Several exceptions occurred during the warmer water periods, on 26 February 2014 (0.23 mg $\left.\mathrm{l}^{-1}\right), 30$ April 2014 (0.11 mg $\left.\mathrm{l}^{-1}\right), 6$ November $2014\left(0.4 \mathrm{mg} \mathrm{l}^{-1}\right)$, 3 March 2015 (0.2 mg $\left.\mathrm{l}^{-1}\right)$, and 1 May $2015\left(0.2 \mathrm{mg} \mathrm{l}^{-1}\right)$. During the winter period of July to August 2014, concentrations were generally above $0.2 \mathrm{mg} \mathrm{l}^{-1}$ (Fig. 4A). Nitrite and nitrate concentrations were low $\left(<0.05 \mathrm{mg} \mathrm{l}^{-1}\right)$ during both summer periods but increased markedly from March to September $2014\left(0.1-0.7 \mathrm{mg} \mathrm{l}^{-1}\right)$. Surface water DRP concentrations were low (average $0.005 \mathrm{mg}^{-1}$ ) from January 2014 to November 2014 , with the highest concentrations $\left(0.02 \mathrm{mg} \mathrm{l}^{-1}\right)$ on 11 March 2014 and 6 November 2014 (Fig. 4B). Concentrations of DRP were higher from December 2014 to May 2015 (average $0.02 \mathrm{mg} \mathrm{l}^{-1}$ ), with three notable peaks on 29 December $2014\left(0.05 \mathrm{mg} \mathrm{l}^{-1}\right), 20$ January $2014\left(0.04 \mathrm{mg} \mathrm{l}^{-1}\right)$, and 26 March 2015 $\left(0.05 \mathrm{mg} \mathrm{l}^{-1}\right)$.

TP and TN were higher during the summer months (January-May) of both years (Fig. 4A, B). Over the period from January to May 2014, the DIN:DRP ratio was highly variable (average of 33), and in 2015, it

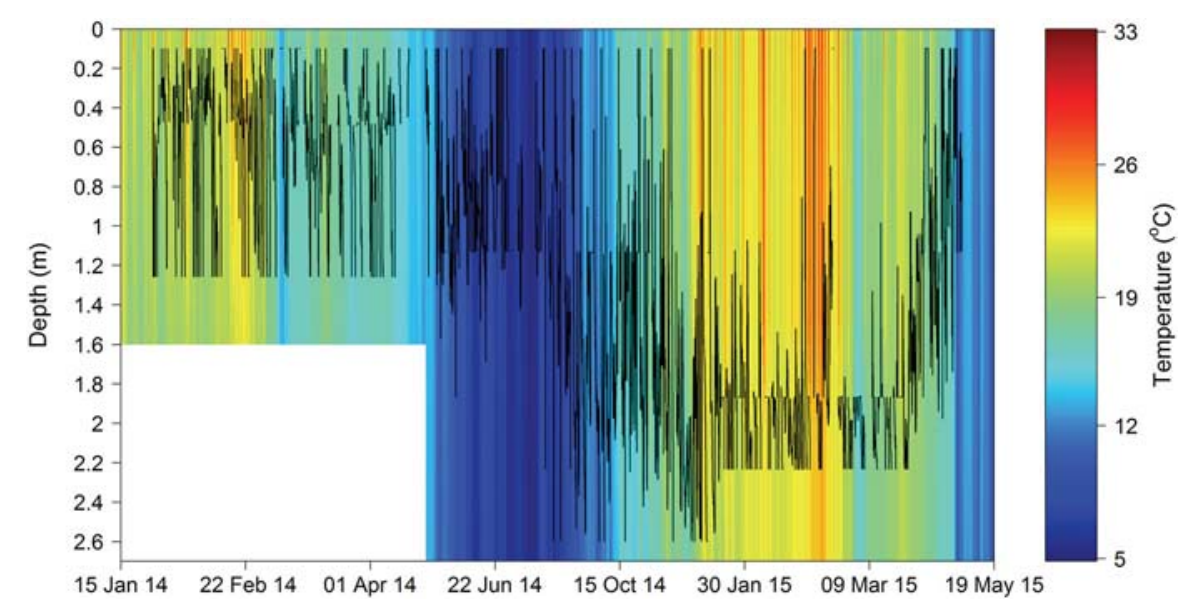

Fig. 2 Temperature contour plot from Lake Rotorua (Kaikoura, New Zealand) over the 17-month study period (January 2014-May 2015). From January to April 2014, the thermistor chain was positioned off the end of the floating pontoon, and thereafter, it was position at a central point in the lake (See Fig. 1 for locations). The white section on the plot is due to the shallower depth of the initial deployment. The black line shows the position of the thermocline 


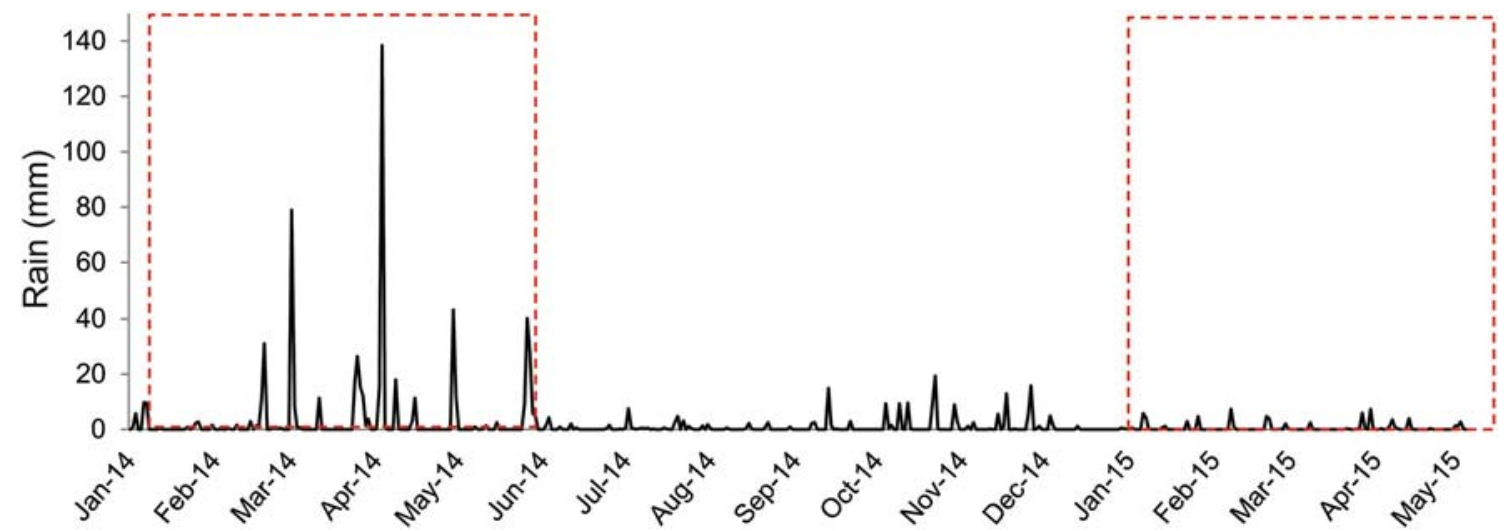

Fig. 3 Total daily rainfall at the Kaikoura Weather Station between January 2014 and May 2015. The red boxes show the two time periods used for comparative purposes in this study

was consistently low (average of 6; Fig. 4C). The TN:TP ratio was $<5$ from January 2014 to April 2015 and increased to $>15$ from May to July 2014. From November 2014 to the conclusion of the study, the TN:TP ratio was relatively constant between 10 and 15 (Fig. 4C).

The ANOVA analysis identified significant differences in summer periods of 2014 and 2015 (assessing only the months of January-May for each year) for a number of physical and chemical parameters (Fig. 5). Higher surface water temperatures $(P<0.01)$, air temperature $(P<0.05)$, and lower rainfall $(P<0.05)$ were observed in 2015 compared to 2014 (Fig. 5). Comparing these two periods, there was a significant increase in the mean TN and DRP concentrations $(P<0.01)$ and TN:TP ratio $(P<0.001)$, and a significant decrease in the DIN:DRP ratio $(P<0.01)$.

Twenty-nine phytoplankton species were recorded in the lake; 3 bacillariophytes, 14 chlorophytes, 1 crytophyta, 1 charophyta, 6 cyanobacteria, 2 dinophytes, 1 euglenophyte, and 1 ochrophyta. Throughout the study period, the dominant phytoplankton phyla were varied; cyanobacteria were dominant at the start of the study until late February 2014; thereafter, chlorophytes (predominantly Dictyosphaerium sp. and Senedesmus spp.) or an euglenophyte (Trachelomonas sp.) were most abundant (Fig. 6).

Of the six cyanobacterial species detected in Lake Rotorua, only four were detected in notable abundance: Aphanocapsa sp., Aphanizomenon gracile Lemmermann, Dolichospermum crassum (Lemmermann) P. Wacklin, L. Hoffmann \& J. Komárek, and
Microcystis aeruginosa (Kützing) Kützing (Fig. 7A). Between 29 January and 22 February 2014, D. crassum dominated the waterbody, reaching a maximum biovolume of $87 \mathrm{~mm}^{3} 1^{-1}$ on 5 February 2014 (Fig. 7A). A. gracile was present at moderate levels $\left(<8 \mathrm{~mm}^{3} \mathrm{l}^{-1}\right)$ and Aphanocapsa sp. at low levels $\left(<0.1 \mathrm{~mm}^{3} \mathrm{l}^{-1}\right)$ during this period (Fig. 7A). Microcystis was observed in samples from 5 February 2014 and became dominant on 5 March 2014 (Fig. 7A).

Over the winter-early spring period of JuneOctober 2014, total cyanobacterial biovolumes were $<1 \mathrm{~mm}^{3} 1^{-1}$ (Fig. 7A). From 15 October 2014 to 9 February 2015, the majority of the total cyanobacterial biovolume was A. gracile (Fig. 7A). From 25 February $2015, D$. crassum accounted for the greatest biovolume of the four species for the remainder of the study period, reaching a maximum of $23 \mathrm{~mm}^{3} \mathrm{l}^{-1}$ on 22 April 2015. This was in contrast to the same period of the previous summer when $D$. crassum was only present at low levels $\left(<1 \mathrm{~mm}^{3} 1^{-1}\right.$; Fig. 7A). $M$. aeruginosa was present in low concentrations $\left(<0.8 \mathrm{~mm}^{3} \mathrm{1}^{-1}\right)$ from 23 October to 26 November 2014. It was not present again until 29 December 2014 and was then observed in all samples until the end of the study, but $M$. aeruginosa biovolumes never exceeded $3 \mathrm{~mm}^{3} \mathrm{l}^{-1}$ (Fig. 7A). Between 9 February and 26 March 2015, Aphanocapsa was present in high concentrations, with biovolumes of ca. $1 \mathrm{~mm}^{3} \mathrm{l}^{-1}$ and a maximum of $3.5 \mathrm{~mm}^{3} \mathrm{l}^{-1}$ (Fig. 7A).

Between January and May 2014, heterocytes occurred in low abundance in $D$. crassum filaments and none were observed in A. gracile filaments 

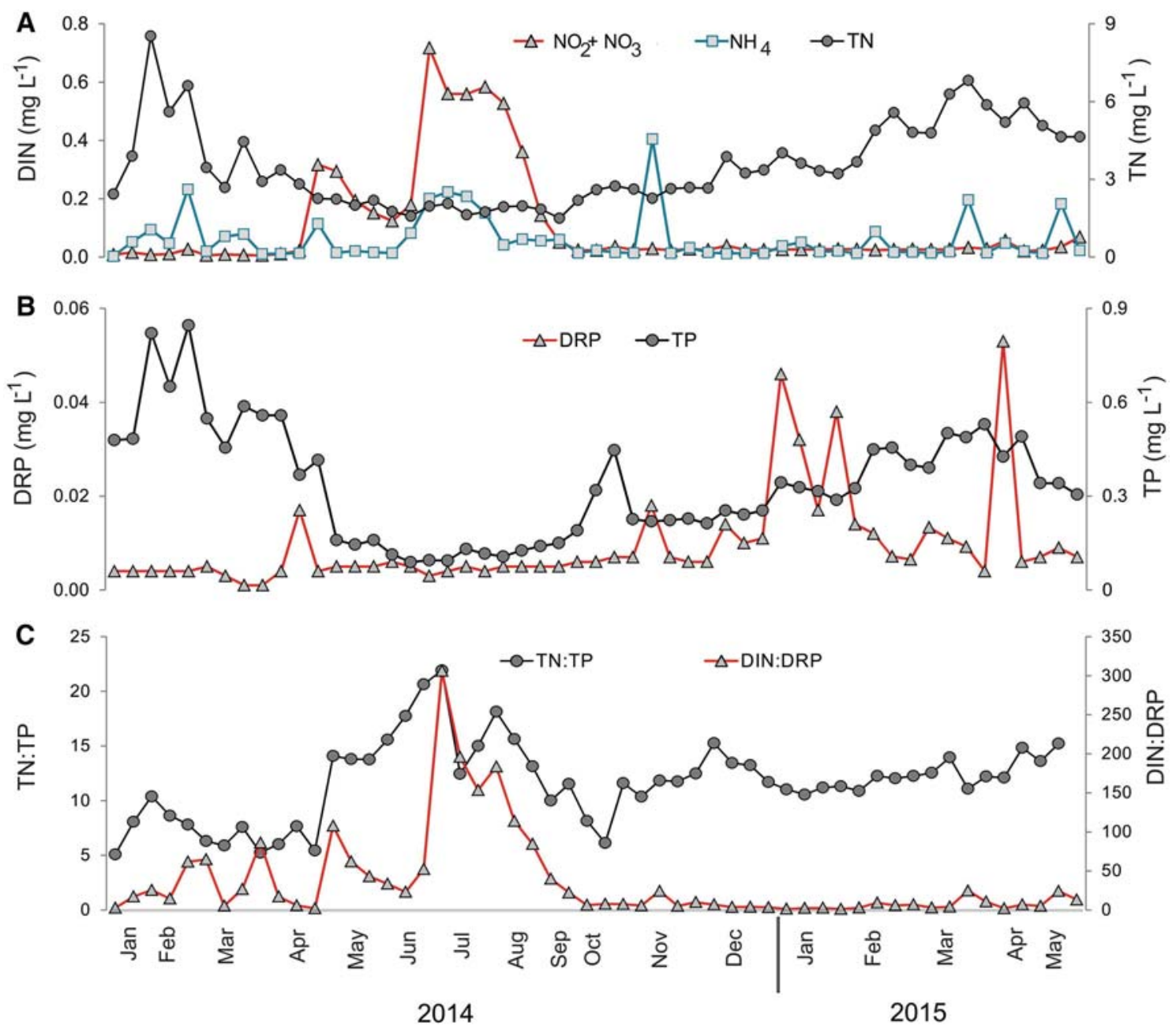

Fig. 4 Nutrient concentrations for Lake Rotorua (Kaikoura, New Zealand) over the 17-month study period of January 2014May 2015; A ammonium $\left(\mathrm{NH}_{4}-\mathrm{N}\right)$, nitrate + nitrite $\left(\mathrm{NO}_{2}+\right.$ $\left.\mathrm{NO}_{3}-\mathrm{N}\right)$, and total nitrogen $(\mathrm{TN})$ concentrations, $\mathbf{B}$ dissolved

(Fig. 7B). In contrast, heterocytes were common in $D$. crassum and $A$. gracile filaments between October 2014 and May 2015 (Fig. 7B). Interestingly, heterocyte frequency in D. crassum was highest prior to the peak biomass of this species, whereas the highest heterocyte frequency in A. gracile occurred after its peak biomass (Fig. 7B).

Microcystins were detected in $43 \%$ of the samples (Fig. 7C). Six microcystin variants were detected during the course of the study: -RR, desmethyl-LR, didesmethyl-LR, -FR, -WR, and -LA, although -FR, WR and -LA were only detected on one occasion (26 April 2014; data not shown). Total microcystin concentrations were generally higher in 2014 than

reactive phosphorus (DRP) and total phosphorus (TP) concentrations, and $\mathbf{C}$ TN:TP and dissolved inorganic nitrogen (DIN):DRP

2015 , with the maximum concentration of $7.2 \mu \mathrm{g} 1^{-1}$ measured in the sample from 19 March 2014 (Fig. 7C). The highest microcystin quotas were measured between 29 January 2014 and 12 February 2014 (1.14-2.14 pg cell ${ }^{-1}$; Fig. 7C) with all other quotas $<0.54 \mathrm{pg} \mathrm{cell}{ }^{-1}$. Marked temporal variability in microcystin quotas was observed, for example, there was a 280 -fold decrease within a 2 -week period (2.14 pg cell ${ }^{-1}$ on 12 February 2014 to 0.01 pg cell $^{-1}$ 26 February 2014; Fig. 7C).

Microcystis genotype composition was highly variable in 2014 (between 1 and 68\% were toxic; Fig. 7D). Although no microcystins were detected, toxic genotypes were measured using QPCR between 

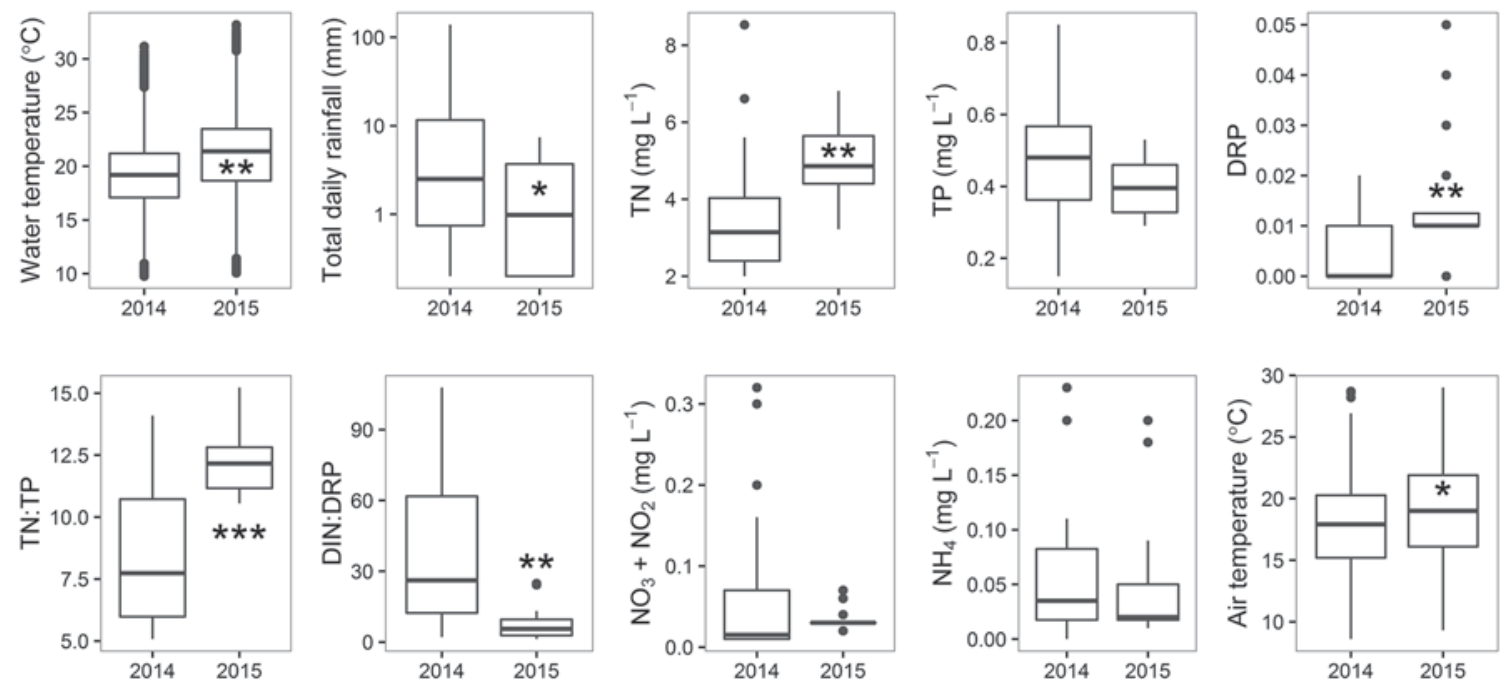

Fig. 5 Boxplot of environmental variables between January and May for 2014 and 2015. Solid black line shows median, box shows first and third quartiles, whiskers extend to the last data point within 1.5 times the inter-quartile range where those data exist. Black dots are outliers beyond this range. Note the log

scale for total daily rainfall. Significant difference between years is indicated: $* P<0.05, * * P<0.01$, and $* * * p<0.001$. $T N$ total nitrogen, $T P$ total phosphorus, $D R P$ dissolved reactive phosphorus, DIN dissolved inorganic nitrogen, $\mathrm{NO}_{3}+\mathrm{NO}_{2}$ nitrate- $\mathrm{N}+$ nitrite-N, $\mathrm{NH}_{4}$ ammonium-N

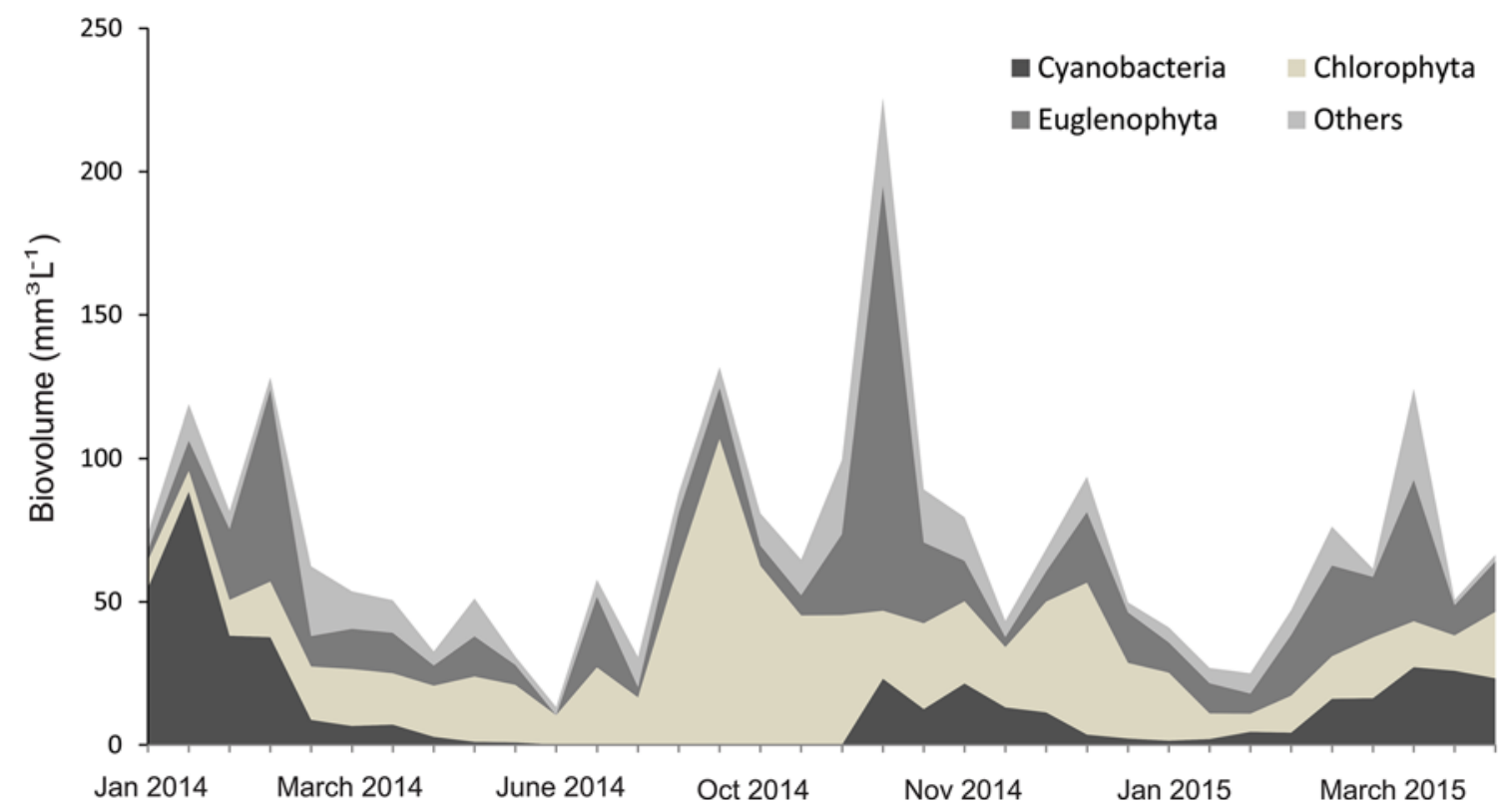

Fig. 6 Phytoplankton biovolumes in water samples from Lake Rotorua (Kaikoura, New Zealand) over the 17-month study period (January 2014-May 2015). Other Bacillariophyta, Dinophyta, Ochrophyta, Charophyta, and Cryptophyta

29 October and 26 November 2015 (1-62\%; Fig. 7D). During the summer of 2015 , the abundance of toxic genotypes was more stable $(32-76 \%)$ declining in relative abundance from the end of March 2015 to the conclusion of the study (Fig. 7D).
Multivariate regression analysis identified six parameters that individually had a significant relationship with the cyanobacterial community composition: $\mathrm{NO}_{3}-\mathrm{N}, \mathrm{TN}, \mathrm{TP}, \mathrm{TN}: \mathrm{TP}, \mathrm{DIN}: \mathrm{DRP}$ and surface water temperature (Table 1A). The sequential model 

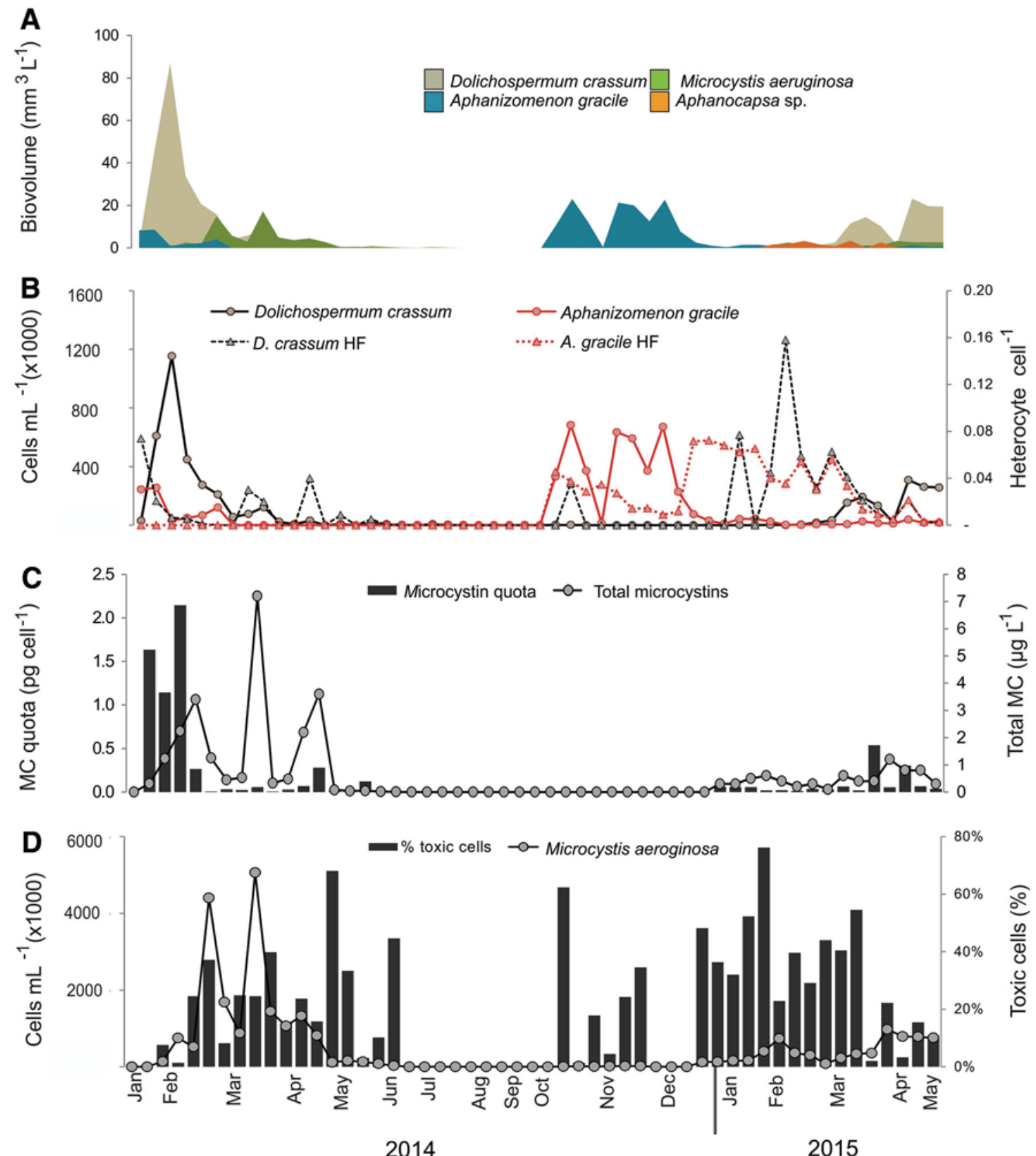

Fig. 7 A Cyanobacterial biovolumes, B heterocyte frequency (HF), C microcystin (MC) quotas of toxic genotypes and total microcystin concentrations, and D Microcystis concentrations

showed that the four variables together explained $53.6 \%$ of the total variation of cyanobacterial community composition (Table 1). The univariate regression analyses indicated a significant $(P<0.001)$ and percentage toxic genotypes in water samples from Lake Rotorua (Kaikoura, New Zealand) over the 17-month study period (January 2014-May 2015)

negative relationship between Microcystis biovolume and TN:TP (Fig. 8A).

Univariate analysis identified a significant positive relationship $(P<0.001)$ between surface water 
temperature and microcystin quota (Fig. 8B). There were no significant relationships between the environmental variables explored and the percentage of toxic Microcystis cells.

\section{Discussion}

Variability in physical and chemical conditions between summers

An increase in the frequency and intensity of rainfall events is one of the predicted outcomes of climate change for some regions of the globe (IPCC, 2007). However, few studies have investigated the direct effect of rainfall on cyanobacterial biomass and composition (reviewed in Reichwaldt \& Ghadouani, 2012). High intensity rainfall events have been shown to cause either a decrease in biomass, or a complete collapse of the bloom due to de-stratification, increased turbidity, dilution, and flushing (Jacobsen \& Simonsen, 1993; Jones \& Poplawski, 1998). These studies concur with our observations in Lake Rotorua, where the most extreme rainfall event (17 April 2014) led to cooling and complete mixing of the water column (Fig. 2) and coincided with a rapid decrease in cyanobacterial biomass $\left(<3 \mathrm{~mm}^{3} 1^{-1}\right.$, which was low on subsequent sampling occasions for around 6 months, until spring; Fig. 7A). Although discharge in the lake outflow was not directly measured, the authors were at the lake on 18 April 2014 and noted an increase in lake level by $>1 \mathrm{~m}$ from observations on the previous day and substantial discharge in the previously dry outflow. Both the lake water outflows had become highly turbid. In contrast, over the same period in 2015 cyanobacterial biovolume remained high $\left(>22 \mathrm{~mm}^{3} \mathrm{1}^{-1}\right)$ until sampling ceased in June (Fig. 7A).

Both prolonged rainfall and intense rainfall events may promote cyanobacterial blooms through increased particulate and soluble nutrient loads entering lakes (Tóth \& Padisák, 1986; Bormans et al., 2005). In Lake Rotorua, there was a marked spike in $\mathrm{NO}_{2}+\mathrm{NO}_{3}-\mathrm{N}$ concentrations in the first sampling (30 April 2014) which was conducted after the 17 April 2014 rainfall event (Figs. 3, 4A). Changes in TP were not observed, suggesting that most of the particulate material flushed

Table 1 Results of non-parametric multiple regression of cyanobacterial community composition on individual environmental variables for: (A) each variable taken individually

(ignoring other variables) and (B) step-wise selection of variables, where variation explained by each variable is added to the model conditional on variables already in the model

\begin{tabular}{|c|c|c|c|c|}
\hline Variables & $F$ & $P$ & $\%$ Var & $\%$ Cum \\
\hline \multicolumn{5}{|l|}{ (A) Marginal test } \\
\hline Nitrite & 1.3 & 0.28 & 2.4 & \\
\hline Nitrate & 10.9 & $<0.001$ & 17.3 & \\
\hline Dissolved reactive phosphorus (DRP) & 1.7 & 0.16 & 3.3 & \\
\hline Ammonium & 0.9 & 0.43 & 1.7 & \\
\hline Total nitrogen $(\mathrm{TN})$ & 21.6 & $<0.001$ & 29.3 & \\
\hline Total phosphorus (TP) & 23.2 & $<0.001$ & 30.8 & \\
\hline TN:TP & 5.0 & $<0.01$ & 8.7 & \\
\hline Dissolved inorganic nitrogen:DRP & 4.9 & $<0.01$ & 8.6 & \\
\hline Surface water temperature & 10.9 & $<0.001$ & 17.4 & \\
\hline Rain & 0.6 & 0.63 & 1.1 & \\
\hline \multicolumn{5}{|l|}{ (B) Sequential test } \\
\hline $\mathrm{TP}$ & 23.2 & $<0.001$ & 30.8 & 30.8 \\
\hline Temperature & 13.6 & $<0.001$ & 14.5 & 45.4 \\
\hline $\mathrm{TN}$ & 5.0 & $<0.01$ & 5.0 & 50.4 \\
\hline DRP & 3.4 & $<0.05$ & 3.3 & 53.6 \\
\hline Nitrite & 2.3 & 0.08 & 2.1 & 55.8 \\
\hline
\end{tabular}

$P$ values in bold are considered significant $(<0.05)$

$\%$ Var percentage of variance in species data explained by that variable, \%Cum. cumulative percentage of variance explained 

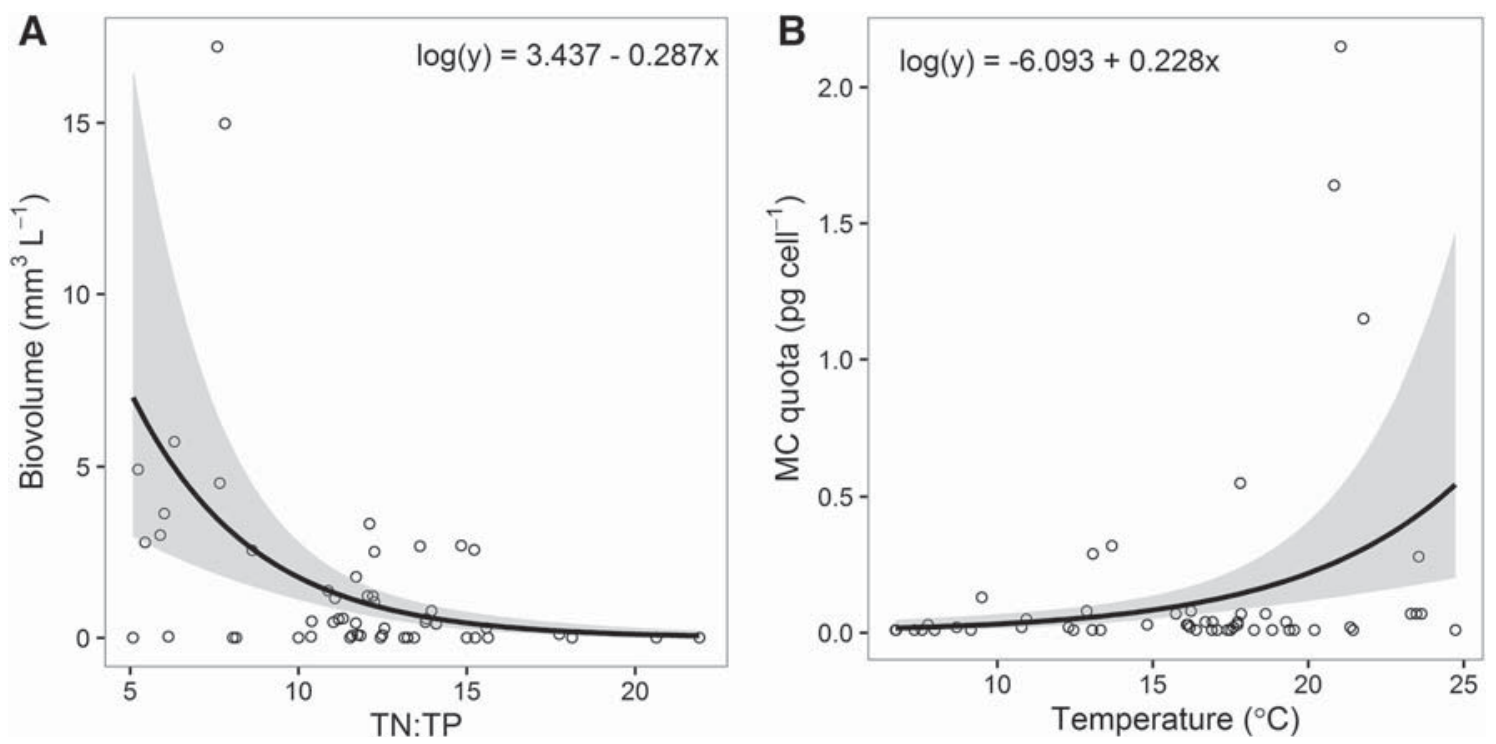

Fig. 8 Relationships between A Microcystis biovolume and ratio of total nitrogen-total phosphorus (TN:TP), and B microcystin (MC) quota and surface water temperature. The shaded area shows the pointwise $95 \%$ confidence interval of the fitted values

into the system had settled within this 2 -week period. Interestingly, possible effects of run-off from less intense rainfall events earlier in the summer were not apparent in the lake nutrient analysis. For example, there was no increase in $\mathrm{NO}_{2}+\mathrm{NO}_{3}-\mathrm{N}$ concentrations following a significant $(79 \mathrm{~mm})$ rainfall event on 15 March 2014 (Figs. 3, 4A). We speculate that the high cyanobacterial and phytoplankton biomass in the lake at this time would have rapidly taken up incoming soluble nutrients (Takamura et al., 1987), resulting in no detectable change in $\mathrm{NO}_{2}+\mathrm{NO}_{3}-\mathrm{N}$ in samples from 19 March 2014 (Fig. 4A). In winter, when cyanobacterial and other phytoplankton biomass was low, rainfall events (e.g. 9 June 2014) usually resulted in a marked increase in water column $\mathrm{NO}_{2}+\mathrm{NO}_{3}-\mathrm{N}$ concentrations (Fig. 4A). Different forms and concentrations of inorganic $\mathrm{N}$ may favour different algal groups. Blomqvist et al. (1994) suggested eukaryotic algae are favoured by $\mathrm{NO}_{3}-\mathrm{N}$. This aligns with the observation of high abundances of chlorophytes and euglenophyte during the winter of 2014 when $\mathrm{NO}_{2}+-$ $\mathrm{NO}_{3}-\mathrm{N}$ concentrations were elevated. Despite the decline in $\mathrm{NO}_{2}+\mathrm{NO}_{3}-\mathrm{N}$ concentrations from September 2014 to the end of the study, the biovolume of eukaryotic algae remained higher than cyanobacteria. This may partly be due to the significant increase in the TN:TP ratio over this period. The optimal ratio for eukaryotic algae is believed to be between 16 and 23 molecules of $\mathrm{N}: 1$ molecule of $\mathrm{P}$, with ratios of 10-16:1 favouring bloom-forming cyanobacteria (Mur et al., 1999).

One of the most notable differences in the cyanobacterial community between the summer periods of 2014 and 2015 was the almost complete absence of heterocytes in A. gracile and D. crassum filaments in 2014, whereas the heterocyte frequency (i.e. relative to vegetative cells) was relatively high in these species throughout 2015 bloom (Fig. 7B). The development of heterocytes in response to low concentrations of dissolved inorganic nitrogen (DIN) has been observed in the field (Laamanen \& Kuosa, 2005; Walve \& Larsson, 2007; Wood et al., 2010) and in laboratory cultures (Zapomělová et al., 2008). The absence of substantial rainfall events in summer 2014 likely reduced the delivery of DIN from catchment sources and created strong DIN limitation on biomass, reinforcing dominance of $\mathrm{N}$-fixing cyanobacteria during the bloom.

Predicted increases in dry periods and increased air temperatures may promote the proliferation of many cyanobacterial species through higher water temperatures and greater water column stability (Jöhnk et al., 2008; Wagner \& Adrian, 2009; Kosten et al., 2012). As predicted, the dry summer of 2015 resulted in significantly warmer air and surface water temperatures (Fig. 5). The two different positions of the thermistor chain in Lake Rotorua in 2014 and 2015 
means a direct comparison of water column temperatures were not possible. There was a prolonged and relatively stable period of stratification (ca. $1.9 \mathrm{~m}$ depth) from mid-January to mid-March in 2015 (Fig. 2). While we did not measure dissolved oxygen, we suggest that this stable stratification would have allowed development of an anoxic hypolimnia promoting the release of nutrients (e.g. DRP and $\mathrm{NH}_{4}-\mathrm{N}$ ) from the bottom sediment (Chorus \& Mur, 1999). Surface water concentrations of DRP were significantly higher in 2015, with the spikes in surface concentrations largely corresponding to periodic destratification events (Fig. 2), likely caused by winddriven mixing and convective cooling.

Cyanobacterial biomass, composition, and succession

In contrast to predictions from climate models and previous culture-/field-based studies, the warmer water temperatures, prolonged stratification, and higher concentrations of DRP in 2015 did not result in an increase in cyanobacterial biomass in Lake Rotorua. The average cyanobacterial biomass between January and May $2015\left(10.7 \mathrm{~mm}^{3} \mathrm{l}^{-1}\right)$ was almost one-half of that of the same period in $2014\left(20 \mathrm{~mm}^{3} \mathrm{1}^{-1}\right)$. Closer examination of the cyanobacterial data provides several possible explanations to this conundrum. First, an average cyanobacterial biovolume of over $10 \mathrm{~mm}^{3} \mathrm{l}^{-1}$ is still extremely high, and there was a persistent dense cyanobacterial bloom during most of the summer in 2015. Second, the 2014 data are skewed by one extremely high biovolume value $\left(87 \mathrm{~mm}^{3} \mathrm{l}^{-1}\right.$ or $1.2 \times 10^{6}$ cells ml ${ }^{-1} ; 2$ February 2014). Removal of this data point reduced the average biovolume across the January-May period to $15 \mathrm{~mm}^{3} 1^{-1}$; however, as noted below this event appears to have had a profound influence on cyanobacterial succession in 2014.

The multiple regression sequential model identified temperature, TP, and TN and as the three most important variables related to cyanobacteria composition over the study period. The temperature at which maximum replication rate occurs varies among cyanobacterial species (Reynolds, 1989, 2006). Additionally, changes in temperature also have indirect effects, or are a response to other events such as stratification, or cooling due to large rainfall events. There is little doubt that temperature plays a direct and indirect role in structuring the cyanobacterial community in Lake Rotorua, and this is discussed in further detail below for specific species. The importance of $\mathrm{N}$ versus $\mathrm{P}$ in explaining total cyanobacterial biovolume and that of specific cyanobacterial taxa has been demonstrated and discussed for many decades (e.g. Smith, 1983; Watson et al., 1997; Vrede et al., 2009; Dolman et al., 2012; Smith et al., 2016). Although the multiple regression identified $\mathrm{N}$ and $\mathrm{P}$ as important, careful consideration of temporal variability, internal, and external fluxes and uptake rates is needed to understand their role in structuring the succession of cyanobacterial communities.

Within the two summers, there was a distinct succession in the cyanobacterial species. In 2014, D. crassum, and to a lesser extent $A$. gracile, initially dominated the biomass (Fig. 7A). Although both species are known $\mathrm{N}$-fixers, the near complete absence of heterocytes in 2014 indicated that no active fixation was occurring and that there was sufficient DIN to support growth. In the sampling immediately after the extremely high biomass event on 2 February 2014 (which was predominantly D. crassum), there was a marked increase in $\mathrm{NH}_{4}-\mathrm{N}$, which may have resulted from the lysis of at least some of this biomass (as previously noted in Wood et al., 2010). Microcystis is extremely adept at utilising $\mathrm{NH}_{4}-\mathrm{N}$ (Blomqvist et al., 1994; Dai et al., 2012), and this in concert with other promoters of $M$. aeruginosa dominance such as high water temperature (Chu et al., 2007; Davis et al., 2009), was likely to have initiated the bloom of this species. After a peak in biomass in February, $M$. aeruginosa declined as DIN decreased. The rainfall event of 15 March 2014 appeared to provide new soluble nutrients, promoting $M$. aeruginosa growth; until cyclone Lusi (17 April 2014) curtailed the bloom, most likely through washout of the biomass. $M$. aeruginosa biomass was markedly lower in 2015, but peaks also coincided with increased concentrations of $\mathrm{NH}_{4}-\mathrm{N}$ in the water. However, in these instances, we suggest that the increased concentrations were likely the result of $\mathrm{NH}_{4}-\mathrm{N}$ release from the sediment, as they occurred with short-term mixing events following a period of sustained stratification. The likely causes for the lower Microcystis biomass observed in 2015, compared to 2014, are that the $2015 \mathrm{NH}_{4}-\mathrm{N}$ pulses were of lower magnitude and did not occur during a period of elevated water temperature, and the TN:TP ratio was consistently high (see "Discussion" section). 
The univariate analysis indicated an inverse relationship between Microcystis biomass and a TN:TP ratio (Fig. 8A). Although early research suggested that this non-N-fixing species would be favoured by higher TN:TP ratios, there is now increasing evidence that corroborates our findings of high biomass associated with low TN:TP (e.g. Marinho \& de Oliveira e Azevedo, 2007; Lehman et al., 2008; Dolman et al., 2012). For example, Takamura et al. (1992) investigated a Microcystis bloom in Lake Kasumigaura and showed that $\mathrm{TN}$ :TP ratios were mostly $<10$ during the bloom, but exceeded 20 after the disappearance of the bloom, a pattern also observed in Lake Rotorua. Beversdorf et al. (2013) noted a similar pattern to that observed in Lake Rotorua during their analysis of a 15-year dataset from the North Temperate Lakes Long Term Ecological Research Program. They found increased M. aeruginosa biomass associated with low $\mathrm{N}: \mathrm{P}$ ratios, while Aphanizomenon, which potentially fixes $\mathrm{N}$, was more likely to occur with higher N:P ratios. Marinho \& de Oliveira e Azevedo (2007) provide evidence to show that low N:P ratios can be the consequence of highuptake capacity and greater relative uptake rates of $\mathrm{N}$ than $\mathrm{P}$ by Microcystis, causing a decrease in the ratio. A similar result was also shown by Xie et al. (2003) although in their experimental setup both $\mathrm{N}$ and $\mathrm{P}$ were supplied in high concentrations.

One of the most notable features of the cyanobacterial community in spring 2014 (October-December) was that it was comprised almost entirely of $A$. gracile. We did not sample over the same period in 2013, preventing an inter-annual comparison. During this period in 2014, the DIN:DRP ratio was extremely low, which is known to favour $\mathrm{N}$-fixing species, and this may be one of the reasons for the dominance of A. gracile during this period (e.g. Vrede et al., 2009). Among $\mathrm{N}$-fixing species, their capacity to fix $\mathrm{N}$ varies. For example, Dolman et al. (2012) noted differences in the $\mathrm{N}$-fixation rate per heterocyte for a variety of nostocalean species. A higher $\mathrm{N}$-fixation capacity in concert with a preference for cooler temperatures (Reynolds, 1989) could explain the dominance of A. gracile during this period. Allelopathy may be a further possible reason for its dominance as Borges et al. (2016) observed benthic Microcystis recruitment in Lake Rotorua was significantly inhibited when $A$. gracile was present in the sediment. Extracts from other Aphanizomenon species are known to inhibit cellular processes in other algae (e.g. Suikkanen et al., 2004).
Aphanocapsa sp. was present only in very low numbers in 2014, yet was abundant between January and April 2015. Aphanocapsa sp. is the smallest (diameter $=0.9 \mu \mathrm{m})$ of the cyanobacteria species observed in Lake Rotorua. The large surface areavolume ratio of picocyanobacteria has been proposed as a reason for their dominance when nutrient concentrations are relatively low (Legendre \& Rassoulzadegan, 1995; Raven, 1998). Thus picocyanobacteria dominance in Lake Rotorua is consistent with low DIN concentrations between January and April 2015.

Havens et al. (2016) examined the effect of extreme weather events and cyclical changes in water level using long-term (15-25 years) datasets from three shallow lakes: Lakes Okeechobee and George (Florida, USA) and Lake Taihu (China). Tropical cyclones resulted in increases in run-off and sediment resuspension, increases in dissolved nutrients, causing intense $M$. aeruginosa booms, findings that concur with many of our observations in Lake Rotorua. In contrast in Lake George, periods of high rainfall resulted in greater dissolved colour, reduced irradiance, and increased water turnover rates which suppress blooms, whereas in dry periods there were dense cyanobacteria blooms. Evaluating the degree to which extreme weather events affect shallow lakes is likely dependant on a myriad of interacting factors including: relative area to mean depths, catchment characteristics, sediment properties, and aquatic vegetation. Additionally our data clearly shows that different cyanobacterial species have diverse responses to varying temperature and stratification, as well as different forms, concentrations and ratios of $\mathrm{N}: \mathrm{P}$. Our results point to the need to differentiate cyanobacterial biomass into species that better reflect their varied physiological attributes, as well to better resolve fluxes of nutrients that affect the competitive attributes of these species.

Variability and drivers of toxic and non-toxic Microcystis genotypes and microcystin quotas

Previous field-based studies have reported positive correlations between toxic Microcystis genotype abundance and TP (Rinta-Kanto et al., 2009; Yu et al., 2014), $\mathrm{NO}_{3}-\mathrm{N}$ (Yoshida et al., 2007) and water temperature (Conradie \& Barnard, 2012). In the present study, no relationships were identified 
between the abundance of toxic genotypes and $M$. aeruginosa biomass or the environmental variables included in our model. To avoid over-parameterising, the model only a limited set of variables were incorporated, including those previously identified as important (or integrators of them such as TN:TP and DIN:DRP). Based on the data in the present study and findings from previous research that indicate a range of environment variables (e.g. temperature, nutrients) influence the relative abundance of toxic and nontoxic genotypes, we suggest that predicting these shifts in cyanobacterial blooms will be extremely challenging. It is likely that variables that drive these changes vary temporally and spatially within and between lakes.

During this study, marked variability in microcystin quota ( $>200$-fold change) was observed over relatively short time frames (ca. 2 weeks). Some of this variation may be attributed to a community shift within the microcystin-producing strains as differences can occur among toxic genotypes, with each producing different microcystin quotas and variants under the same conditions (Saker et al., 2005; Krüger et al., 2010). As the QPCR assay used in this study only discriminates between toxic and non-toxic genotypes, no information on strain-level diversity was collected during the study.

The univariate modelling used in the present study identified a significant positive relationship between microcystin quotas and surface water temperature. This corroborates earlier reports suggesting that microcystin concentrations are maximal around 20-25 ${ }^{\circ} \mathrm{C}$ (Van der Westhuizen \& Eloff, 1985; Watanabe \& Oishi, 1985; van der Westhuizen et al., 1986; Amé \& Wunderlin, 2005) and highlights the possibility that predicted global increases in surface water temperature may lead to higher microcystin quotas. It is also possible that the higher surface water temperatures could select for toxin-producing strains which produce higher microcystin quotas, but as noted above we were not able to ascertain this using the QPCR assay.

The discrepancy between times of maximal Microcystis biovolumes, toxic genotype abundance, and microcystin quotas highlights the challenges for water managers trying to estimate periods of highest risk when relying solely on the cell concentration (or biovolume) data recommended by numerous guidelines (WHO, 2003; NHMRC, 2008; Wood et al., 2009).
For example, the second highest total microcystin concentrations detected in a water sample $\left(3.6 \mu \mathrm{g}{ }^{-1}\right.$, 30 April 2014) occurred when Microcystis biovolumes were moderate $\left(2.8 \mathrm{~mm}^{3} \mathrm{l}^{-1}\right)$, the abundance of toxic genotypes was low (16\%), and the microcystin quota was at intermediate levels $\left(0.2 \mathrm{pg} \mathrm{cell}^{-1}\right)$. To provide greater assurance in estimating risk from cyanotoxin exposure, parallel cyanobacterial identification, enumeration, and toxin analysis are recommended. These data are essential to enable a progression from current models of Microcystis biomass or specific physiological attributes of cyanobacteria (see Oliver et al., 2012), to in situ genotype composition and microcystin production, including how these variables might respond under predicted climatic change scenarios.

\section{Conclusions}

This study demonstrates the interactive effects that varying precipitation and temperature can have on physical, chemical, and biological parameters in shallow eutrophic lakes. The key differences observed in Lake Rotorua were higher $\mathrm{NO}_{3}-\mathrm{N}$ inputs during the wet summer, prolonged stratification, and increased DRP and low DIN concentrations in the drier warmer summer. Corresponding differences were observed in the cyanobacterial communities that reflected their varying physiological adaptations (e.g. N-fixation, nutrient uptake capacity, and temperature optima). No relationships between environmental parameters and shifts in toxic/non-toxic Microcystis genotypes were identified, although there was a positive relationship between temperature and microcystin quota. We suggest that while generalised prediction on how Microcystis biomass might alter under foreseen climate change scenarios are feasible, determining how genotype composition and microcystin production will vary is extremely challenging.

Acknowledgments This research was supported by the Marsden Fund of the Royal Society of New Zealand (12UOW-087; Toxic in Crowds), the New Zealand Ministry of Business, Innovation and Employment (UOWX1503; Enhancing the Health and Resilience of New Zealand Lakes), the Royal Society of New Zealand International Research Staff Exchange Scheme Fellowship (MEAT Agreement 295223) and the Marie Curie International Research Staff Exchange Scheme Fellowship (PIRSES-GA-2011-295223). We thank Spencer and Thomas Kahu for sample collection, and the 
Kahu family, Ngāi Tahu and Environment Canterbury for allowing access to Lake Rotorua. We acknowledge Kati Doehring and Weimin Jiang (Cawthron) for assistance with Figs. 1 and 2, respectively.

\section{References}

Ahn, C. Y., H. M. Oh \& Y. S. Park, 2011. Evaluation of environmental factors on cyanobacterial bloom in eutrophic reservoir using artificial neural networks. Journal of Phycology 47: 495-504.

Amé, M. \& D. Wunderlin, 2005. Effects of iron, ammonium and temperature on microcystin content by a natural concentrated Microcystis aeruginosa population. Water, Air, and Soil Pollution 168: 235-248.

Anderson, M., R. N. Gorley \& K. R. Clarke, 2008. PERMANOVA + for PRIMER: Guide to Software and Statistical Methods. PRIMER-E, Plymouth: 214 pp.

APHA, 2005. Standard Methods for the Examination of Water and Wastewater, 21st edn. American Public Health Association (APHA), American Water Works Association (AWWA) and Water Environment Federation (WEF): $541 \mathrm{pp}$.

Baker, P. D. \& L. D. Fabbro, 2002. A Guide to the Identification of Common Blue-Green Algae (Cyanoprokaryotes) in Australian Freshwaters, 2nd edn. Cooperative Research Centre for Freshwater Ecology, Australia: 56 pp.

Beversdorf, L. J., T. R. Miller \& K. D. McMahon, 2013. The role of nitrogen fixation in cyanobacterial bloom toxicity in a temperate, eutrophic lake. PLoS One 8: e56103.

Blomqvist, P., A. Petterson \& P. Hyenstrand, 1994. Ammonium-nitrogen: a key regulatory factor causing dominance of non-nitrogen-fixing cyanobacteria in aquatic systems. Archiv für Hydrobiologie 132: 141-164.

Bolch, C. J. S. \& S. I. Blackburn, 1996. Isolation and purification of Australian isolates of the toxic cyanobacterium Microcystis aeruginosa Kütz. Journal of Applied Phycology 8: 5-13.

Borges, H., S. A. Wood, J. Puddick, E. Blaney, I. Hawes, D. R. Dietrich \& D. P. Hamilton, 2016. Intracellular, environmental and biotic interactions influence recruitment of benthic Microcystis (Cyanophyceae) in a shallow eutrophic lake. Journal of Plankton Research. doi:10.1093/plankt/ fbw046.

Bormans, M., P. W. Ford \& L. Fabbro, 2005. Spatial and temporal variability in cyanobacterial populations controlled by physical processes. Journal of Plankton Research 27: 61-70.

Brookes, J. D. \& C. C. Carey, 2011. Resilience to blooms. Science 334: 46-47.

Cai, Y. \& F. Kong, 2013. Diversity and dynamics of picocyanobacteria and the bloom-forming cyanobacteria in a large shallow eutrophic lake (Lake Chaohu, China). Journal of Limnology 72: 473-484.

Carey, C. C., B. W. Ibelings, E. P. Hoffmann, D. P. Hamilton \& J. D. Brookes, 2012. Eco-physiological adaptations that favour freshwater cyanobacteria in a changing climate. Water Research 46: 1394-1407.
Chorus, I., 2001. Cyanotoxins - Occurrence, Causes, Consequences. Springer Berlin Heidelberg, Berlin: 357 pp.

Chorus, I. \& L. Mur, 1999. Preventive measures. In Chorus, I. \& J. Bartram (eds), Toxic Cyanobacteria in Water - A Guide to their Public Health Consequences, Monitoring and Management. E and FN Spon, London: 235-273.

Chu, Z., X. Jin, N. Iwami \& Y. Inamori, 2007. The effect of temperature on growth characteristics and competitions of Microcystis aeruginosa and Oscillatoria mougeotii in a shallow, eutrophic lake simulator system. In Qin, B., Z. Liu \& K. Havens (eds), Eutrophication of Shallow Lakes with Special Reference to Lake Taihu, China. Springer, Dordrecht: 217-223.

Clearwater, S. J., S. A. Wood, N. R. Phillips, S. M. Parkyn, R. van Ginkel \& K. J. Thompson, 2014. Toxicity thresholds for juvenile freshwater mussels Echyridella menziesii and crayfish Paranephrops planifrons, after acute or chronic exposure to Microcystis sp. Environmental Toxicology 29: 487-502.

Codd, G., L. Morrison \& J. Metcalf, 2005. Cyanobacterial toxins: risk management for health protection. Toxicology and Applied Pharmacology 203: 264-272.

Conley, D. J., H. W. Paerl, R. W. Howarth, D. F. Boesch, S. P. Seitzinger, K. E. Havens, C. Lancelot \& G. E. Likens, 2009. Controlling eutrophication: nitrogen and phosphorus. Science 323: 1014-1015.

Conradie, K. R. \& S. Barnard, 2012. The dynamics of toxic Microcystis strains and microcystin production in two hypertrophic South African reservoirs. Harmful Algae 20: $1-10$.

Dai, G. Z., J.-L. Shang \& B. S. Qiu, 2012. Ammonia may play an important role in the succession of cyanobacterial blooms and the distribution of common algal species in shallow freshwater lakes. Global Change Biology 18: 1571-1581.

Davis, T. W., D. L. Berry, G. L. Boyer \& C. J. Gobler, 2009. The effects of temperature and nutrients on the growth and dynamics of toxic and non-toxic strains of Microcystis during cyanobacteria blooms. Harmful Algae 8: 715-725.

Dolman, A. M., J. Rucker, F. R. Pick, J. Fastner, T. Rohrlack, U. Mischke \& C. Wiedner, 2012. Cyanobacteria and cyanotoxins: the influence of nitrogen versus phosphorus. PLoS One 7: e38757.

Dziallas, C. \& H. P. Grossart, 2011. Increasing oxygen radicals and water temperature select for toxic Microcystis sp. PLoS One 6: e25569.

Fernández, C., V. Estrada \& E. Parodi, 2015. Factors triggering cyanobacteria dominance and succession during blooms in a hypereutrophic drinking water supply reservoir. Water, Air, Soil and Pollution 226: 1-13.

Flint, E., 1975. Phytoplankton in some New Zealand lakes. In Jolly, V. H. \& J. M. Brown (eds), New Zealand Lakes. Auckland University Press, Auckland: 63-192.

Garcia-Pichel, F., J. Belnap, S. Neuer \& F. Schanz, 2003. Estimates of global cyanobacterial biomass and its distribution. Algological Studies 109: 213-227.

Hamilton, D. P., S. A. Wood, D. R. Dietrich \& J. Puddick, 2014 Costs of harmful blooms of freshwater cyanobacteria. In Sharma, N. K., A. K. Rai \& S. J. Lucas (eds), Cyanobacteria: An Economic Perspective. Wiley, New York: 245-256. 
Harke, M. J. \& C. J. Gobler, 2013. Global transcriptional responses of the toxic cyanobacterium, Microcystis aeruginosa, to nitrogen stress, phosphorus stress, and growth on organic matter. PLoS One 8: e69834.

Harke, M. J., M. M. Steffen, C. J. Gobler, T. G. Otten, S. W. Wilhelm, S. A. Wood \& H. W. Paerl, 2016. A review of the global ecology, genomics, and biogeography of the toxic cyanobacterium, Microcystis spp. Harmful Algae 54: 4-20.

Haugland, R. A., S. C. Siefring, L. J. Wymer, K. P. Brenner \& A. P. Dufour, 2005. Comparison of Enterococcus measurements in freshwater at two recreational beaches by quantitative polymerase chain reaction and membrane filter culture analysis. Water Research 39: 559-568.

Havens, K., H. Paerl, E. Phlips, M. Zhu, J. Beaver \& A. Srifa, 2016. Extreme weather events and climate variability provide a lens to how shallow lakes may respond to climate change. Water 8: 229.

Horst, G. P., O. Sarnelle, J. D. White, S. K. Hamilton, R. B. Kaul \& J. D. Bressie, 2014. Nitrogen availability increases the toxin quota of a harmful cyanobacterium, Microcystis aeruginosa. Water Research 54: 188-198.

IPCC, 2007. Contribution of Working Group I to the Fourth Assessment Report of the Intergovernmental Panel on Climate Change. In Solomon, S., D. Qin, M. Manning, Z. Chen, M. Marquis, K. B. Averyt, M. Tignor \& H. L. Miller (eds), Climate Change 2007: The Physical Science Basis. Cambridge University Press, Cambridge.

Jacobsen, B. \& P. Simonsen, 1993. Disturbance events affecting phytoplankton biomass, composition and species diversity in a shallow, eutrophic, temperate lake. In Padisák, J., C. S. Reynolds \& U. Sommer (eds), Intermediate Disturbance Hypothesis in Phytoplankton Ecology. Springer, Dordrecht: 9-14

Jöhnk, K. D., J. E. F. Huisman, J. Sharples, B. E. N. Sommeijer, P. M. Visser \& J. M. Stroom, 2008. Summer heatwaves promote blooms of harmful cyanobacteria. Global Change Biology 14: 495-512.

Jones, G. J. \& W. Poplawski, 1998. Understanding and management of cyanobacterial blooms in sub-tropical reservoirs of Queensland, Australia. Water Science and Technology 37: 161-168.

Kleinteich, J., S. A. Wood, F. C. Kupper, A. Camacho, A. Quesada, T. Frickey \& D. R. Dietrich, 2012. Temperaturerelated changes in polar cyanobacterial mat diversity and toxin production. Nature Climate Change 2: 356-360.

Komárek, J. \& K. Anagnostidis, 1999. Süßwasserflora von Mitteleuropa: Cyanoprokaryota 19/1. Teil: Chroococcales. Springer Spektrum, Berlin.

Kosten, S., V. L. M. Huszar, E. Bécares, L. S. Costa, E. van Donk, L. A. Hansson, E. Jeppesen, C. Kruk, G. Lacerot, N. Mazzeo, L. De Meester, B. Moss, M. Lürling, T. Nõges, S. Romo \& M. Scheffer, 2012. Warmer climates boost cyanobacterial dominance in shallow lakes. Global Change Biology 18: 118-126.

Kouzminov, A., J. Ruck \& S. A. Wood, 2007. New Zealand risk management approach for toxic cyanobacteria in drinking water. Australian and New Zealand Journal of Public Health 31: 275-281.

Krüger, T., C. Wiegand, L. Kun, B. Luckas \& S. Pflugmacher, 2010. More and more toxins around-analysis of cyanobacterial strains isolated from Lake Chao (Anhui Province, China). Toxicon 56: 1520-1524.

Kurmayer, R. \& T. Kutzenberger, 2003. Application of realtime PCR for quantification of microcystin genotypes in a population of the toxic cyanobacterium Microcystis sp. Applied and Environmental Microbiology 69: 6723-6730.

Laamanen, M. \& H. Kuosa, 2005. Annual variability of biomass and heterocysts of the $\mathrm{N}_{2}$-fixing cyanobacterium Aphanizomenon flos-aquae in the Baltic Sea with reference to Anabaena spp. and Nodularia spumigena. Boreal Environment Research 10: 19-30.

Legendre, L. \& F. Rassoulzadegan, 1995. Plankton and nutrient dynamics in marine waters. Ophelia 41: 153-172.

Lehman, P. W., G. Boyer, M. Satchwell \& S. Waller, 2008. The influence of environmental conditions on the seasonal variation of Microcystis cell density and microcystins concentration in San Francisco Estuary. Hydrobiologia 600: $187-204$

Lewis, W. M. \& W. A. Wurtsbaugh, 2008. Control of lacustrine phytoplankton by nutrients: erosion of the phosphorus paradigm. International Review of Hydrobiology 93: 446-465.

Marinho, M. \& S. M. F. de Oliveira e Azevedo, 2007. Influence of N/P ratio on competitive abilities for nitrogen and phosphorus by Microcystis aeruginosa and Aulacoseira distans. Aquatic Ecology 41: 525-533.

McArdle, B. H. \& M. J. Anderson, 2001. Fitting multivariate models to community data: a comment on distance-based redundancy analysis. Ecology 82: 290-297.

McGregor, G. \& L. D. Fabbro, 2001. A Guide to the Identification of Australian Freshwater Planktonic Chroococcales (Cyanoprokaryota/Cyanobacteria). Cooperative Research Centre for Freshwater Ecology, Australia: 61 pp.

Mur, L. R., O. M. Skulberg \& H. Utkilen, 1999. Cyanobacteria in the environment. In Chorus, I. \& J. Bartram (eds), Toxic Cyanobacteria in Water: A Guide to Their Public Health Consequences, Monitoring and Management. Published on Behalf of the World Health Organisation by E and FN Spon, London: 15-40.

NHMRC, 2008. Guidelines for Managing Risks in Recreational Water. National Health and Medical Research Council, Canberra.

Ni, W. M., J. Y. Zhang, T. D. Ding, R. J. Stevenson \& Y. M. Zhu, 2012. Environmental factors regulating cyanobacteria dominance and microcystin production in a subtropical lake within the Taihu watershed, China. Journal of Zhejiang University, SCIENCE A 13: 311-322.

O’Neil, J. M., T. W. Davis, M. A. Burford \& C. J. Gobler, 2012. The rise of harmful cyanobacteria blooms: the potential roles of eutrophication and climate change. Harmful Algae 14: 313-334.

Oliver, R. L., D. P. Hamilton, J. D. Brookes \& G. G. Ganf, 2012. Physiology, blooms and prediction of planktonic cyanobacteria. In Whitton, B. A. (ed.), Ecology of Cyanobacteria II: Their Diversity in Space and Time. Springer, Dordrecht: 155-194.

Paerl, H. W., 2014. Mitigating harmful cyanobacterial blooms in a human- and climatically-impacted world. Life 4: 988-1012.

Paerl, H. W. \& J. Huisman, 2008. Blooms like it hot. Science 320: $57-58$. 
Paerl, H. W. \& J. Huisman, 2009. Climate change: a catalyst for global expansion of harmful cyanobacterial blooms. Environmental Microbiology Reports 1: 27-37.

Paerl, H. \& T. Otten, 2013. Harmful cyanobacterial blooms: causes, consequences, and controls. Microbial Ecology 65: 995-1010.

Paerl, H. W. \& V. J. Paul, 2012. Climate change: links to global expansion of harmful cyanobacteria. Water Research 46 : 1349-1363.

Paerl, H., L. Valdes, A. Joyner, B. Peierls, M. Piehler, S. Riggs, R. Christian, L. Eby, L. Crowder, J. Ramus, E. Clesceri, C. Buzzelli \& R. Luettich, 2006. Ecological response to hurricane events in the Pamlico Sound system, North Carolina, and implications for assessment and management in a regime of increased frequency. Estuaries and Coasts 29: 1033-1045.

Pinheiro, J. \& D. Bates, 2000. Mixed-Effects Models in S and S-PLUS. Springer, New York.

R Development Core Team, 2014. R: A Language and Environment for Statistical Computing. R Foundation for Statistical Computing, Vienna [available on internet at http:// www.R-project.org/].

Rajaniemi-Wacklin, P., A. Rantala, P. Kuuppo, K. Haukka \& K. Sivonen, 2008. Cyanobacterial community composition in shallow, eutrophic Lake Tuusulanjärvi studied by microscopy, strain isolation, DGGE and cloning. Algological Studies 126: 137-157.

Raven, J. A., 1998. The twelfth Tansley Lecture. Small is beautiful: the picophytoplankton. Functional Ecology 12: 503-513.

Reichwaldt, E. S. \& A. Ghadouani, 2012. Effects of rainfall patterns on toxic cyanobacterial blooms in a changing climate: between simplistic scenarios and complex dynamics. Water Research 46: 1372-1393.

Reynolds, C. S., 1989. Physical determinants of phytoplankton succession. In Sommer, U. (ed.), Plankton Ecology. Springer Berlin Heidelberg, Berlin: 9-56.

Reynolds, C. S., 2006. The Ecology of Phytoplankton. Cambridge University Press, Cambridge.

Rinta-Kanto, J. M., E. A. Konopko, J. M. DeBruyn, R. A. Bourbonniere, G. L. Boyer \& S. W. Wilhelm, 2009. Lake Erie Microcystis: relationship between microcystin production, dynamics of genotypes and environmental parameters in a large lake. Harmful Algae 8: 665-673.

Rogers, S., 2014. Investigation of microcystin processing, production and export by Microcystis sp. Masters of Science Thesis, University of Waikato, Hamilton.

Rueckert, A. \& S. C. Cary, 2009. Use of an armored RNA standard to measure microcystin synthetase $\mathrm{E}$ gene expression in toxic Microcystis sp. by reverse-transcription QPCR. Limnology and Oceanography: Methods 7: 509-520.

Saker, M. L., J. Fastner, E. Dittmann, G. Christiansen \& V. M. Vasconcelos, 2005. Variation between strains of the cyanobacterium Microcystis aeruginosa isolated from a Portuguese river. Journal of Applied Microbiology 99: 749-757.

Schindler, D. W., R. E. Hecky, D. L. Findlay, M. P. Stainton, B. R. Parker, M. J. Paterson, K. G. Beaty, M. Lyng \& S. E. M. Kasian, 2008. Eutrophication of lakes cannot be controlled by reducing nitrogen input: results of a 37 -year whole- ecosystem experiment. Proceedings of the National Academy of Sciences of USA 105: 11254-11258.

Smith, V. H., 1983. Low nitrogen to phosphorus ratios favor dominance by blue-green algae in lake phytoplankton. Science 221: 669-671.

Smith, V. H., 2003. Eutrophication of freshwater and coastal marine ecosystems a global problem. Environmental Science and Pollution Research 10: 126-139.

Smith, V. H., S. A. Wood, C. G. McBride, J. Atalah, D. P. Hamilton \& J. Abell, 2016. Phosphorus and nitrogen loading restraints are essential for successful eutrophication control of Lake Rotorua, New Zealand. Inland Waters 6: 273-283.

Steffensen, D. A., 2008. Economic cost of cyanobacterial blooms. Advances in Experimental Medicine and Biology 619: 855-865.

Suikkanen, S., G. O. Fistarol \& E. Granéli, 2004. Allelopathic effects of the Baltic cyanobacteria Nodularia spumigena, Aphanizomenon flos-aquae and Anabaena lemmermannii on algal monocultures. Journal of Experimental Marine Biology and Ecology 308: 85-101.

Sun, J. \& D. Liu, 2003. Geometric models for calculating cell biovolume and surface area for phytoplankton. Journal of Plankton Research 25: 1331-1346.

Takamura, N., T. Iwakuma \& M. Yasuno, 1987. Uptake of 13C and $15 \mathrm{~N}$ (ammonium, nitrate and urea) by Microcystis in Lake Kasumigaura. Journal of Plankton Research 9: $151-165$.

Takamura, N., A. Otsuki, M. Aizaki \& Y. Nojiri, 1992. Phytoplankton species shift accompanied by transition from nitrogen dependence to phosphorus dependence of primary production in Lake Kasumigaura, Japan. Archiv für Hydrobiologie 124: 129-148.

Tóth, L. G. \& J. Padisák, 1986. Meteorological factors affecting the bloom of Anabaenopsis raciborskii Wolosz. (Cyanophyta: Hormogonales) in the shallow Lake Balaton, Hungary. Journal of Plankton Research 8: 353-363.

Trolle, D., D. P. Hamilton, C. A. Pilditch, I. C. Duggan \& E. Jeppesen, 2010. Predicting the effects of climate change on trophic status of three morphologically varying lakes: implications for lake restoration and management. Environmental Modelling and Software 26: 354-370.

Utermöhl, H., 1958. Towards a perfection of quantitative phytoplankton methodology. Verhandlungen der Internationalen Vereinigung für Theoretische und Angewandte Limnologie 9: 1-38.

Vaitomaa, J., A. Rantala, K. Halinen, L. Rouhiainen, P. Tallberg, L. Mokelke \& K. Sivonen, 2003. Quantitative realtime PCR for determination of microcystin synthetase E copy numbers for Microcystis and Anabaena in lakes. Applied and Environmental Microbiology 69: 7289-7297.

Van de Waal, D. B., J. M. Verspagen, J. F. Finke, V. Vournazou, A. K. Immers, W. E. Kardinaal, L. Tonk, S. Becker, E. Van Donk, P. M. Visser \& J. Huisman, 2011. Reversal in competitive dominance of a toxic versus non-toxic cyanobacterium in response to rising $\mathrm{CO}_{2}$. The ISME Journal 5: 1438-1450.

Van der Westhuizen, A. J. \& J. N. Eloff, 1985. Effect of temperature and light on the toxicity and growth of the bluegreen alga Microcystis aeruginosa (UV-006). Planta 163: $55-59$. 
van der Westhuizen, A. J., J. N. Eloff \& G. H. J. Krüger, 1986. Effect of temperature and light (fluence rate) on the composition of the toxin of the cyanobacterium Microcystis aeruginosa (UV-006). Archiv für Hydrobiologie 108: $145-154$.

Vrede, T., A. Ballantyne, C. Mille-Lindblom, G. Algesten, C. Gudasz, S. Lindahl \& A. K. Brunberg, 2009. Effects of N:P loading ratios on phytoplankton community composition, primary production and $\mathrm{N}$ fixation in a eutrophic lake. Freshwater Biology 54: 331-344.

Wagner, C. \& R. Adrian, 2009. Cyanobacteria dominance: quantifying the effects of climate change. Limnology and Oceanography 54: 2460-2468.

Walve, J. \& U. Larsson, 2007. Blooms of Baltic Sea Aphanizomenon sp. (Cyanobacteria) collapse after internal phosphorus depletion. Aquatic Microbial Ecology 49: 57-69.

Watanabe, M. F. \& S. Oishi, 1985. Effects of environmental factors on toxicity of a cyanobacterium (Microcystis aeruginosa) under culture conditions. Applied and Environmental Microbiology 49: 1342-1344.

Watson, S. B., E. McCauley \& J. A. Downing, 1997. Patterns in phytoplankton taxonomic composition across temperate lakes of differing nutrient status. Limnology and Oceanography 42: 487-495.

WHO, 2003. Guidelines for Safe Recreational Water Environments: Coastal and Fresh Waters. World Health Organization, Geneva.

Wood, S. A., A. L. M. Crowe, J. G. Ruck \& R. G. Wear, 2005. New records of planktonic cyanobacteria in New Zealand freshwaters. New Zealand Journal of Botany 43: 479-492.

Wood, S. A., D. P. Hamilton, W. J. Paul, K. A. Safi \& W. M. Williamson, 2009. New Zealand Guidelines for Cyanobacteria in Recreational Fresh Waters. Ministry for the Environment and the Ministry of Health, Wellington.

Wood, S. A., M. J. Prentice, K. Smith \& D. P. Hamilton, 2010. Low dissolved inorganic nitrogen and increased heterocyte frequency: precursors to Anabaena planktonica blooms in a temperate, eutrophic reservoir. Journal of Plankton Research 32: 1315-1325.

Wood, S. A., A. Rueckert, D. P. Hamilton, S. C. Cary \& D. R. Dietrich, 2011. Switching toxin production on and off: intermittent microcystin synthesis in a Microcystis bloom. Environmental Microbiology Reports 3: 118-124.

Wood, S. A., D. R. Dietrich, C. S. Cary \& D. P. Hamilton, 2012a. Increasing Microcystis cell density enhances microcystin synthesis: a mesocosm study. Inland Waters 2 : $17-22$.

Wood, S. A., N. R. Phillips, M. de Winton \& M. Gibbs, 2012b. Consumption of benthic cyanobacterial mats and nodularin-R accumulation in freshwater crayfish (Paranephrops planifrons) in Lake Tikitapu (Rotorua, New Zealand). Harmful Algae 20: 175-179.

Wood, S. A., J. Puddick, H. Borges, D. R. Dietrich \& D. P. Hamilton, 2015. Potential effects of climate change on cyanobacterial toxin production. In Botana, L. M., C. Louzao \& N. Vilariño (eds), Climate Change and Marine and Freshwater Toxins. De Gruyter, Berlin: 155-180.

Xie, L., P. Xie, S. Li, H. Tang \& H. Liu, 2003. The low TN:TP ratio, a cause or a result of Microcystis blooms? Water Research 37: 2073-2080.

Yoshida, M., T. Yoshida, Y. Takashima, N. Hosoda \& S. Hiroishi, 2007. Dynamics of microcystin-producing and nonmicrocystin-producing Microcystis populations is correlated with nitrate concentration in a Japanese lake. FEMS Microbiology Letters 266: 49-53.

Yu, L., F. Kong, M. Zhang, Z. Yang, X. Shi \& M. Du, 2014. The dynamics of Microcystis genotypes and microcystin production and associations with environmental factors during blooms in Lake Chaohu, China. Toxins 6: 3238-3257.

Zapomělová, E., P. Hrouzek, K. Řeháková, M. Šabacká, M. Stibal, L. Caisová, J. Komárková \& A. Lukešová, 2008. Morphological variability in selected heterocystous cyanobacterial strains as a response to varied temperature, light intensity and medium composition. Folia Microbiology 53: 333-341.

Zuur, A. F., E. N. Ieno \& C. S. Elphick, 2010. A protocol for data exploration to avoid common statistical problems. Methods Ecology and Evolution 1: 3-14.

Zuur, A. F., J. M. Hilbe \& E. N. Ieno, 2013. A Beginner's Guide to GLM and GLMM with R: A Frequentist and Bayesian perspective for Ecologists. Highland Statistics, Newburgh. 